\title{
(Re)translating Horace into Ukrainian Modernity: From Mykola Zerov to Andrii Sodomora
}

\author{
Lada Kolomiyets \\ Taras Shevchenko National University of Kyiv
}

\begin{abstract}
This article focuses on the history of translations and the reasons for translating the Roman classics into Ukrainian in the late twentieth to early twentyfirst centuries, as illustrated by the case of Horace. Translation practices, as well as the socio-cultural status and habitus of the translator-classicist, have been varied but have intersected in many respects throughout the twentieth century. This article highlights the major developments in the approach to translating Horace throughout the twentieth century. It mostly focuses on the attitudes and strategies of Mykola Zerov and Andrii Sodomora, who are among the key figures in the twentieth-century theory and practice of translation in Ukraine. The first major development comprises the critical debate regarding translation in the 1920s initiated by Mykola Khvyl'ovyi, whose position was supported by Zerov. The article discusses both the translation practice of Zerov and his reader-oriented theory of verse translation. The second crucial point consists of the revision by Sodomora, starting from the 1980s, of a paraphrasing strategy worked out by Zerov. In his retranslation strategy, applied to his earlier translations from Horace and substantiated in his literary essays, Sodomora exhibits a positive reconsideration of the role and importance of literalist precision in translating the Roman classics, as exemplified by Horace. Sodomora's evolving approach toward higher precision in translating the classics stems from a close reading of the authentic cultural contexts, structural poetics, philosophical messages, and hidden intertextuality of the source texts. Also, it resonates with Walter Benjamin's model of literalism, which in many respects appears useful when applied to post-Soviet literary conditions in Ukraine.
\end{abstract}

Keywords: Horace, retranslation, paraphrasing strategy, neo-literalist strategy, golden mean.

\section{INTRODUCTION}

$\mathrm{D}$ uring the Ukrainian National Renaissance (or Revival) of the 1920s and early1930s (which has been termed the "Executed Renaissance"1) and before the Iezhov Terror (aka the Great Stalinist Purge), Ukrainian

\footnotetext{
1 This term was introduced by Ukrainian literary scholar Iurii Lavrinenko in his annotated collection, called Rozstriliane vidrodzhennia (Executed Renaissance), of the best literary works of 1917-33, first printed in 1959.
}

(C) 2019 East/West: Journal of Ukrainian Studies (ewjus.com) ISSN 2292-7956

Volume VI, No. 2 (2019) DOI: https://doi.org/10.21226/ewjus531 
theories of translation took a leadership role in Soviet critical thinking in this field. Ukrainian classicist scholars and translators-in particular, Mykola Zerov (1890-1937), Volodymyr Derzhavyn (1899-1964), and Oleksandr Bilets'kyi (1884-1961) — were at the forefront of developments in the theory and practice of translating the ancient classics.

Much attention in discussions at that time was devoted to translation style. The flexible approach to translating directly into Ukrainian from the source text language developed by Derzhavyn and like-minded critics oriented Ukrainian readers to the source text authors and their native country, rather than replacing the source text's linguistic and cultural realities with analogous ones in the target language. Derzhavyn developed a theory of homological translation, which was oriented toward formal patterns (metrical and euphonic structure, word order) as well as the figurative language of the source text-so that the translation could be called literal in terms of its semantic and stylistic accuracy, but was not literal in the sense of a word-for-word translation. Superficial literalness was closer to Derzhavyn than analogical translation, which is abundantly re-creative and oriented around the compositional and linguistic patterns already existing in the target language, to the detriment of the source text's originality. Of those two types (homological and analogical translation), Derzhavyn decisively prefers and praises homological, or stylizing, translation ("Problema virshovanoho perekladu").

The dichotomy of the strategies sketched out by Derzhavyn correlates with the theory of foreignizing versus domesticating translation developed by Lawrence Venuti in the late 1980s and early1990s-specifically, in Venuti's introduction to the 1992 collection of articles Rethinking Translation: Discourse, Subjectivity, Ideology and in his 1995 monograph The Translator's Invisibility: A History of Translation. Venuti lays a foundation of the "visible" translation-foreignization as opposed to the "invisible" translationdomestication, which is analogous to the translation of a poem written in a foreign language being received by the target audience as if it had been created in their native tongue. Just as Derzhavyn did in his articles, Venuti gives priority to semantically and stylistically accurate translation (or "translation-stylization," in Derzhavyn's definition), which is not supposed to be comprehended fluently by the target audience.

This fundamental requirement of stylistic accuracy in translation, brought into focus by Derzhavyn in his consistent advocacy of the foreignizing strategy, appeared to have been unparalleled in the Ukrainian literary context of the mid- and late 1920s. But such viewpoints were not at odds with the broader European context of that decade. Moreover, Derzhavyn's conception of homological translation turned out to be particularly attuned to Walter Benjamin's pursuit of ideal translation. One of the epoch-making philosophers and cultural critics, from the mid-1950s

(C) 2019 East/West: Journal of Ukrainian Studies (ewjus.com) ISSN 2292-7956

Volume VI, No. 2 (2019) 
Benjamin (1892-1940) became, posthumously, an important and often-cited thinker. His early essay "Die Aufgabe des Übersetzers" ("The Task of the Translator," 1923) reveals the narrator's preoccupation with a new approach to translation that would deviate from the then-traditional assimilative approach. This essay lay the groundwork for the late twentiethcentury turn in translation studies. Inter alia, Venuti draws on Benjamin and his concepts of foreignization. Benjamin's view of radical literalness as a passageway that signifies approximation to the purposiveness of a foreign language "in a constant state of flux" coheres with Derzhavyn's prioritization of stylistic accurateness in translation (not fixed meanings). Benjamin explains that

[W]hile all individual elements of foreign languages-words, sentences, structure-are mutually exclusive, these languages supplement one another in their intentions. Without distinguishing the intended object from the mode of intention, no firm grasp of this basic law of a philosophy of language can be achieved. The words Brot and pain "intend" the same object, but the modes of this intention are not the same. It is owing to these modes that the word Brot means something different to a German than the word pain to a Frenchman, that these words are not interchangeable for them, that, in fact, they strive to exclude each other. As to the intended object, however, the two words mean the very same thing. (75)

Both theorists, Benjamin and Derzhavyn, were adamant that the style of the original linguistic creation-its fluctuating "mode of intention," in Benjamin's terminology - should be given priority over the fixed content as an "intended object."

As Hryhorii Maifet ${ }^{2}$ puts it, Derzhavyn was the first translation scholar who produced "a coherent theory, which could not help but have a substantial impact" (Review of Teoriia i praktyka 339). Derzhavyn was promoting extremely severe requirements for translation, which were for the most part shared by the master of classical poetry translation, literary critic and editor Mykola Zerov.

Zerov belonged to a group of Kyivan poets who represented the socalled Neoclassical school (with Zerov, Pavlo Fylypovych, Maksym Ryl's'kyi, Mykhailo Drai-Khmara, and Oswald Burghardt [Iurii Klen] as its members). He was a helpful and tireless adviser for many a translator of his time. Zerov was a most knowledgeable and productive literary editor, provided reviews and critiques of published translations, carried out stylistic edits of books in translation, prefaced several of them, and wrote a large number of analytical essays on the works of Ukrainian and foreign writers.

${ }^{2}$ Hryhorii Maifet (1903-75) was a notable Ukrainian literary critic and specialist in Western European and North American literature.

(C) 2019 East/West: Journal of Ukrainian Studies (ewjus.com) ISSN 2292-7956

Volume VI, No. 2 (2019) 
The biggest opponent of Derzhavyn among his contemporary fellow critics was Oleksandr Finkel' (1899-1968), who authored the first academic book on translation not only in the Ukrainian SSR but also in the entire Soviet Union, written in Ukrainian and titled Teoriia i praktyka perekladu (Theory and Practice of Translation, 1929). He was also one of the leading Soviet translation scholars - along with Kornei Chukovskii and Andrei Fedorov, who jointly authored the first Russian-language academic book on translation, Iskusstvo perevoda (The Art of Translation, 1930). In contrast to Derzhavyn, Finkel' proposed a view of literary translation as a creative activity that has certain restrictions and requires a more conscious approach than just a free flight on the wings of inspiration.

The leading Ukrainian Neoclassical poets-Zerov and Ryl's'kyi in particular-explored the ancient Roman idea of combining the useful ("utile") with the pleasant ("dulci"), which was vividly formulated by Horace (Quintus Horatius Flaccus, b. 8 December 65 BC, d. 27 November 8 BC) in his treatise on versification "Ars Poetica" (The Art of Poetry), aka "Epistle to the Pisos" (ca. 19 BC), a poetic letter written in hexameter verse. This illustrates the idea of delivering useful philosophical maxims to the readers via pleasant poetic images. The Neoclassical poets substantially domesticated and paraphrased the originals in their translation practice. They rationalized the delivery of "useful" philosophical content of ancient poetry via familiar rhythms and images.

Meanwhile, the distinguished contemporary translator Andrii Sodomora (born 1937) was convinced that the unity of cognitive value (usefulness) and esthetic value (pleasure)—or, simply, the unity of thought and image, which is the most essential feature of Horace and, generally, of the authors of Roman antiquity - should also comprise unity in translation. When translated without this unity, the original Horatian poetry loses its vital poetic quality, i.e., ceases to be poetry in its ancient Roman measure and context.

\section{Horace in Zerov's Paraphrasing Strategy ("Aurea mediocritas" as TEMPERANCE)}

Not only was Mykola Zerov the leading translator of the 1920s, he was also an exemplary model for Ukrainian translators of the Roman classics throughout the twentieth century. Apart from the lost translation of Virgil's narrative poem The Aeneid (only some fragments of it have survived ${ }^{3}$ ), Zerov

\footnotetext{
${ }^{3}$ In the twentieth century, Zerov's ambitious plan to translate the entire Aeneid was eventually implemented by Mykhailo Bilyk (1889-1970), a Ukrainian literary critic, linguist, and translator of the works of ancient Greek and Roman poets, including

(C) 2019 East/West: Journal of Ukrainian Studies (ewjus.com) ISSN 2292-7956

Volume VI, No. 2 (2019)
} 
has left a rather extensive selection of verse translations from Latin. Antolohiia ryms'koi poezii (An Anthology of Roman Poetry: 22 works by Catullus, Virgil, Horace, Propertius, Ovid, and Martial), compiled and translated by Zerov, was published by Drukar in Kyiv in 1920. However, this was just the beginning of a large, unfinished work of translating ancient Roman authors, a project the poet pursued until his death.

Horace was one of Zerov's favourite classical authors. He translated twenty-four of Horace's odes, two epodes, and one satire. As a proponent of "aurea mediocritas" ("the golden mean"), Horace gained in Zerov the fame of a cold Parnassian because of Zerov's understanding of the Horatian rule of harmony as temperance-though not as the emotional detachment Horace has been framed for by a superficial reading of Zerov's translations.

Horatian works became known in Ukraine at the turn of the sixteenth century. Among the first Ukrainian interpreters of Horace was Pavlo Rusyn of Krosno (Pavlo Krosnianyn), ${ }^{4}$ a Latin-language poet, scholar, and publisher, who established his own poetic school. The Horatian treatise "The Art of Poetry" formed the basis of a range of ancient Ukrainian Poetics. The famous Ukrainian philosopher Hryhorii Skovoroda (1722-94), a great fan and connoisseur of Horatian poetry, retold several of his odes in the Old Ukrainian language. The poet, fabulist, and scholar Petro HulakArtemovs'kyi (1790-1825) rewrote six of Horace's odes in a mocking manner that was popular at the time. One of the greatest contributors to Ukrainian literature and a polyglot translator, Ivan Franko (1856-1916) translated only three Horatian poems, from his first Book of Odes. Ivan Franko's son Taras translated or satirized nearly 30 Horatian odes. In 1901, the literary scholar and writer Vasyl' Shchurat (1871-1948) published a book of 22 selected odes of Horace in his own translation in Peremyshl (now Przemyśl, Poland). Also, besides Zerov's and Sodomora's translations, Horace's works were translated into Ukrainian by other noted scholars and writers of the twentieth century-Andrii Bilets'kyi, Mykhailo Bilyk, Hryhorii Kochur, and Borys Ten (Zahais'ka 38).

Anacreon, Tyrtaeus, Theognis, Horace, and Tibullus. But Bilyk's main achievement, according to researchers of Ukrainian literature, is his translation of The Aeneid. Books I-VI of the epic poem were published in the town of Stryi in Western Ukraine in 1931. The full-length translation was completed in the city of Lviv after World War II. It was only thanks to the public support of two authoritative Ukrainian writers, Oles' Honchar and Dmytro Pavlychko, that the complete translation of The Aeneid appeared in Soviet Ukraine (published by Dnipro in Kyiv in 1972). A reprint of Bilyk's translation appeared in 2003 with the Kharkiv publishing house Folio.

${ }^{4}$ As stated in Ancient Literature Breaking Down Stereotypes, "he was born approx. in 1470 on the lands inhabited by Lemkos" (Shevchenko-Savchynska and Balashov 60).

(C) 2019 East/West: Journal of Ukrainian Studies (ewjus.com) ISSN 2292-7956

Volume VI, No. 2 (2019) 
In his Ukrainian translations of Horatian poems Zerov practiced a higher fidelity to Horatian style than Shchurat, and strove for organic unity of poetic form and content (Tvory $)^{5}$. To allow readers a closer look at his translation strategy in action, Table 1 below sets forth, in the left-hand column, the full text of Horace's "Ode to Melpomene," aka "The Monument" (Ode 3.30)—in which Horace predicts his own enduring, immortal fame-together with its line-by-line metrical translation by A. S. Kline (The Odes: Book III). And the right-hand column provides Zerov's syllabo-tonic Ukrainian translation, rhymed and performed in four quatrains, belonging to the 1920s (first printed in 1938), which I accompany with my interlinear translation into English (Tvory 297-98).

Table 1. “Ode to Melpomene” by Horace.

\begin{tabular}{|c|c|}
\hline $\begin{array}{l}\text { Horace's "Ode to Melpomene" } \\
(\text { Ode } 3.30) \text { and its interlinear } \\
\text { metrical translation into } \\
\text { English by A.S. Kline }\end{array}$ & $\begin{array}{l}\text { Zerov's Ukrainian translation of Horace's } \\
\text { "Ode to Melpomene," accompanied by my } \\
\text { interlinear English translation }\end{array}$ \\
\hline $\begin{array}{l}1 \text { Exegi monumentum aere } \\
\text { perennius, } \\
\text { I've raised a monument, more } \\
\text { durable than bronze, } \\
2 \text { regalique situ pyramidum } \\
\text { altius, } \\
\text { one higher than the Pyramids' } \\
\text { royal towers, }\end{array}$ & $\begin{array}{l}1 \text { Мій пам'ятник стоїть триваліший від } \\
\text { міді. } \\
\text { My monument stands more lasting than } \\
\text { bronze. } \\
2 \text { Піднісся він чолом над царські піраміди. } \\
\text { It has raised its forehead above the royal } \\
\text { pyramids. }\end{array}$ \\
\hline $\begin{array}{l}3 \text { quod non imber edax, non } \\
\text { Aquilo impotens } \\
\text { that no devouring rain, or fierce } \\
\text { northerly gale, }\end{array}$ & $\begin{array}{l}3 \text { Його не сточить дощ уїдливий, } \\
\text { гризький, } \\
\text { It will not be eroded by rain, corrosive, biting, }\end{array}$ \\
\hline $\begin{array}{l}4 \quad \text { possit diruere aut } \\
\text { innumerabilis } \\
\text { has power to destroy: nor the } \\
\text { immeasurable }\end{array}$ & $\begin{array}{l}4 \text { Не звалить налітни́й північний буревій, } \\
\text { Nor be thrown down by a swooping northern } \\
\text { storm, }\end{array}$ \\
\hline
\end{tabular}

\footnotetext{
${ }^{5}$ In its turn, the publication of Horatian poetry in Zerov's translation in the first volume of the 1990 edition of the Works in Two Volumes by Mykola Zerov is a reprint from his earlier publication Kvint Horatsii Flakk.
} 
Table 1 Cont.

\begin{tabular}{|c|c|}
\hline $\begin{array}{l}\text { Horace's “Ode to Melpomene" } \\
(\text { Ode } 3.30) \text { and its interlinear } \\
\text { metrical translation into English } \\
\text { by A.S. Kline }\end{array}$ & $\begin{array}{l}\text { Zerov's Ukrainian translation of Horace's } \\
\text { "Ode to Melpomene," accompanied by my } \\
\text { interlinear English translation }\end{array}$ \\
\hline $\begin{array}{l}5 \text { annorum series et fuga temporum. } \\
\text { succession of years, and the swift } \\
\text { passage of time. }\end{array}$ & $\begin{array}{l}5 \text { Ні років довгий ряд, ні часу літ } \\
\text { невпинний; } \\
\text { Or a long row of years, or unstoppable flight } \\
\text { of time; }\end{array}$ \\
\hline $\begin{array}{l}6 \text { Non omnis moriar, multaque pars } \\
\text { mei } \\
\text { I'll not utterly die, but a rich part of } \\
\text { me, }\end{array}$ & $\begin{array}{l}6 \text { Я не умру цілком: єства мого частина } \\
\text { I will not die entirely: a part of my nature }\end{array}$ \\
\hline $\begin{array}{l}7 \text { vitabit Libitinam. Usque ego } \\
\text { postera } \\
\text { will escape Persephone: and fresh } \\
\text { with the praise }\end{array}$ & $\begin{array}{l}7 \text { Переживе мене, і від людських сердець } \\
\text { Will outlive me, and from people's hearts }\end{array}$ \\
\hline $\begin{array}{l}8 \text { crescam laude recens. Dum } \\
\text { Capitolium } \\
\text { of posterity, I'll rise, beyond. While } \\
\text { the High }\end{array}$ & $\begin{array}{l}8 \text { Прийматиму хвалу, поки понтифік- } \\
\text { жрець } \\
\text { I will accept praise, as long as the chief high } \\
\text { priest }\end{array}$ \\
\hline $\begin{array}{l}9 \text { scandet cum tacita virgine } \\
\text { pontifex. } \\
\text { Priest, and the silent Virgin, climb } \\
\text { the Capitol, }\end{array}$ & $\begin{array}{l}9 \text { Ще сходить } 3 \text { дівою в високий Капітолій. } \\
\text { Still ascends with the virgin into the high } \\
\text { Capitol. }\end{array}$ \\
\hline $\begin{array}{l}10 \text { dicar, qua violens obstrepit } \\
\text { Aufidus } \\
\text { I'll be famous, I, born of humble } \\
\text { origin, }\end{array}$ & $\begin{array}{l}10 \text { І де шумить Авфід в нестриманій } \\
\text { сваволі, } \\
\text { And where the Aufidus River roars in } \\
\text { unrestrained self-will, }\end{array}$ \\
\hline $\begin{array}{l}11 \text { et qua pauper aquae Daunus } \\
\text { agrestium } \\
\text { (from where wild Aufidus roars, } \\
\text { and where Daunus once, }\end{array}$ & $\begin{array}{l}11 \text { I де казковий Давн ратайський люд } \\
\text { судив,- } \\
\text { And where fabled Daunus judged the } \\
\text { plowmen - }\end{array}$ \\
\hline
\end{tabular}


Table 1 Cont.

\begin{tabular}{|c|c|}
\hline $\begin{array}{l}\text { Horace's "Ode to Melpomene" } \\
\text { (Ode } 3.30 \text { ) and its interlinear } \\
\text { metrical translation into } \\
\text { English by A.S. Kline }\end{array}$ & $\begin{array}{l}\text { Zerov's Ukrainian translation of Horace's } \\
\text { “Ode to Melpomene," accompanied by my } \\
\text { interlinear English translation }\end{array}$ \\
\hline $\begin{array}{l}12 \text { regnavit populorum ex } \\
\text { humili potens, } \\
\text { lacking in streams, ruled over a } \\
\text { rural people) }\end{array}$ & $\begin{array}{l}12 \text { Скрізь говоритимуть, що, про́стих син } \\
\text { батьків, } \\
\text { Everywhere they will say that a son of low- } \\
\text { born parents, }\end{array}$ \\
\hline $\begin{array}{l}13 \text { princeps Aoelium carmen ad } \\
\text { Italos } \\
\text { as the first to re-create Aeolian } \\
\text { song }\end{array}$ & $\begin{array}{l}13 \text { Я перший положив на італійську міру } \\
\text { I was the first to adapt to Italian measure }\end{array}$ \\
\hline $\begin{array}{l}14 \text { deduxisse modos. Sume } \\
\text { superbiam } \\
\text { in Italian verse. Melpomene, } \\
\text { take pride, }\end{array}$ & $\begin{array}{l}14 \text { Еллади давній спів. Так не таїсь від } \\
\text { миру, } \\
\text { The ancient song of Hellas. Thus, do not hide } \\
\text { from the world, }\end{array}$ \\
\hline $\begin{array}{l}15 \text { quaesitam meritis et mihi } \\
\text { Delphica } \\
\text { in what has been earned by your } \\
\text { merit, and, Muse, }\end{array}$ & $\begin{array}{l}15 \text { I лавром, що зростив святий } \\
\text { дельфійський гай, } \\
\text { And with the laurel grown by the sacred } \\
\text { Delphian grove, }\end{array}$ \\
\hline $\begin{array}{l}16 \text { lauro cinge volens, } \\
\text { Melpomene, comam. } \\
\text { willingly, crown my hair, with } \\
\text { the Delphic laurel. }\end{array}$ & $\begin{array}{l}16 \text { О Мельпомено, ти чоло моє звінчай! } \\
\text { O Melpomene, do crown my forehead. }\end{array}$ \\
\hline
\end{tabular}

Horace used a variety of metres in Book III, always designing his poetry for recitation, i.e., for oral performance, not for silent reading. The fact that he masterfully introduced an assortment of rare and refined metres to the Latin art of versification has notably contributed to his long-lasting fame and respect. Ode 30 from this book is written in the first Asclepiadean verse, a standard line of which consists of 12 syllables: 6 long and 6 short syllables, with a slight variation, reflected in the following scheme: UUŨ|ŪUUŪ||ŪUUŪ|UŨ, where "Ū" denotes a long syllable, "U" a short one, and "Ũ" is an anceps syllable, which can be either short or long; "|" denotes a foot boundary and "II" a diaeresis (the break in a line, where the end of a foot coincides with the end of a word).

Kline, the author of the above-given metrical translation of Ode 30 , explains in the "Translator's Note" that "Horace fully exploited the metrical possibilities offered to him by Greek lyric verse," and on this basis the 
translator has followed "the original Latin metre in all cases, giving a reasonably close English version of Horace's strict forms" (The Odes: Book III). As Kline aphoristically sums it up, "Rhythm, not rhyme, is the essence" of Horace's poetry (The Odes: Book III).

Side-by-side with Zerov's translation, the Ode looks unnatural when divided into quatrains. However, in subsequent Ukrainian interpretations it remains divided into quatrains, as a tribute to Zerov's initial rendition. While the poetic craft of Horace manifested itself in finding the rare and exquisite metres and applying them in his own verses, Zerov aims at a fluent sound of the poem in Ukrainian. He transforms the originally versatile Asclepiadean verse-the Horatian rhythmical pattern in the poem-into a rather monotonous, drum-type sounding iambic hexameter (with an extra, unaccented syllable, or a truncated foot, in lines one and two of each quatrain). The number of syllables per line in each of the quatrains is 13-1312-12. Schematically, each stanza in the Zerov rendition has the following metrical pattern:

$$
\begin{aligned}
& \text { UÚ|UÚ|UÚ|UÚ|UÚ|UÚ|U } \\
& \text { UÚ|UÚ|UÚ|UÚ|UÚ|UÚ|U } \\
& \text { UÚ|UÚ|UÚ|UÚ|UÚ|UÚ } \\
& \text { UÚ|UÚ|UÚ|UÚ|UÚ|UÚ }
\end{aligned}
$$

where "Ú" denotes an accented syllable, "U" an unaccented one, and "|" is a foot boundary.

Zerov rhymes his translation of the Ode, and in doing so he follows the national (i.e., Ukrainian-language) versification tradition. Throughout the poem, he introduces adjacent end-rhymes, or rhyming couplets, so that the rhyme scheme looks as follows: AABBCCDDEEFFGGHH. Specifically, he suggests in the 1st stanza (rhymes are given in bold font): vid midi piramidy, hryz'kyi - burevii; in the 2nd stanza: Nevpynnyi - chastyna, (liuds'kykh) serdets' - (pontyfik-)zhrets'; in the 3rd stanza: Kapitolii svavoli, sudyv - bat'kiv; and in the 4th stanza: miru-myru, (del'fiis'kyi) hai - zvinchai. Because of the application of rhymes and digression from the original rhythmical pattern, Zerov's translation of Ode 30 is mostly considered a free rendition. ${ }^{6}$

On the whole, Zerov's attitude to translating the Roman classics, and Horace in particular, constitutes a notable example of selective strategy. According to Zerov, the secondary, accidental details have to remain in the shadow, or even be left untranslated, while the main purpose of the translator is to render the integrity, the continuity of a literary work.

\footnotetext{
6 For instance, see the editor's commentary on Zerov's translation of the Ode, published in Antychna literatura: Khrestomatiia (Ancient Literature: An Anthology) (Bilets'kyi).
}

(C) 2019 East/West: Journal of Ukrainian Studies (ewjus.com) ISSN 2292-7956

Volume VI, No. 2 (2019) 
As can be seen, Zerov renders with high precision the overall story told by Horace, though departing from accurateness in detail and embellishing the imagery of the Ode with figurative language. Further are some examples of Zerov's elaboration on the original imagery: "pidnissia vin cholom"- "it has raised its forehead" (periphrasis), "uidlyvyi, hryz'kyi"-"corrosive, biting" (synonymic pair), "rokiv dovhyi riad"- “a long row of years" (added epithet), "Ellady davnii spiv"—“the ancient song of Hellas" (added epithet), "ne stochyt"'-“will not be eroded"; "ne zvalyt"'-"nor be thrown down" (metaphoric verbs), "iestva moho chastyna"-"a part of my nature" (periphrasis), "vid liuds'kykh serdets"'- “'from people's hearts” (periphrasis), "ratais'kyi liud" - "the plowmen" (periphrasis), "prostykh syn bat'kiv"—“a son of low-born parents" (periphrasis), "skriz' hovorytymut"'-"everywhere they will say" (added phrase), "tak ne tais' vid myru" — "thus, do not hide from the world" (added phrase), "shcho zrostyv sviatyi del'fiis'kyi hai" — "grown by the sacred Delphian grove" (added clause), "ty cholo moie zvinchai"-_do crown my forehead" (synecdoche). Zerov also uses two lexemes of distinctly literary origin-"iestvo" (meaning "the essence of something, the most important in something") in the phrase "iestva moho chastyna" and "cholo" ("the forehead") in the phrase "cholo moie zvinchai" — which appear to be highly conducive to emotional intensification of the persona's diction in the poem.

The cognitive value of art, which "helps" the reader, and the esthetic value, which "amuses" him-as pointed out by Horace in his "Epistle to the Pisos," better known by the name "Ars Poetica" — can also be applied to the art of translating. Zerov was among those who wanted to combine the cognitive and esthetic value of Horace's art for the broadest audience of Ukrainian readers. However, in translation these two qualities comprise almost incompatible goals.

With the purpose of producing a balanced translation, Zerov unifies not so much the language, which in his works is rather flexible, fresh, and not overly set, as he averages the style, i.e., the metres and consequently the style. Having replaced the heterogeneous rhythms of the original (in one poem this is a combination of trochees and dactyls, while in another poem the combination is different) with the customary iamb, he increases the number of syllables - in particular, by ten more in each stanza in "Do Favna" ("Ode to Faunus"), and by doing so procures for himself the space for various compensations (Zerov, Tvory 295-96). He also increases the number of epithets and gives extended paraphrases, sometimes with exquisite metaphorical images, etc. The overall strategy of compensation, broadly applied by Zerov, contradicts the literalist's belief in the importance of rendering the wording of the original. Besides, the tonality of Zerov's paraphrasing translations not infrequently appears to be quite remote from that of Horace's. 
For all these reasons, the contemporary poet-translator and professor of classical philology Sodomora considers the main strategy of Zerov in his interpretations of the classics to be a free, creative paraphrase, as he remarks in his 2006 collection of articles Studii odnoho virsha (The Study of a Single Poem,${ }^{7}$ having observed that Zerov gives exquisite metaphorical paraphrases where in Horace the reader encounters extremely circumspect verbal landscapes (122-23). The tonality that predominates in such paraphrases appears to be remote from the source text. In such translations, Sodomora sums up, the reader will not find a pathway back to the original, because the translator simply has not paved the way (Studii 124).

III. ZEROV'S READER-ORIENTED THEORY OF VERSE TRANSLATION: AWAY FROM THE Colonial PAST AND FROM CULTURAL PROVINCIALISM

Zerov took an active part in the literary polemics of 1925-26, sharing Mykola Khvyl'ovyi's ${ }^{8}$ pivotal concern regarding the low quality of literary output for the masses, as well as his ardent search for a literary orientation toward the European classical heritage and Western civilizational values. Seven polemical articles by Zerov, published as a separate book in 1926, created a coherent motivational platform for Khvyl'ovyi's eccentric and excessively emotional pamphlets, which unmasked a slavish dependence on Russian paragons in Ukrainian literature and debunked epigonism, esthetic inferiority, and a lack of education among the mass-produced Ukrainian peasant and proletarian writers. The collection of Zerov's polemical articles was demonstrably titled Do dzherel (To the Sources)-a response to Khvyl'ovyi's question "Quo vadis?"

Zerov pointed to Europe and European culture: "We must get to know the sources of European culture, and we must make them our own. We must know them, or else we shall always be provincials. To Khvylovy's 'Quo vadis?' let us answer: ad fontes, to the original sources, to the roots" (Do dzherel 72; translation in Shkandrij 72).

And Zerov expressed his full support for Khvyl'ovyi's emotional appeals to improve the quality and to Europeanize Ukrainian literature at several public debates as well. In particular, at a so-called "Dispute" held on 24 May

\footnotetext{
7 Sodomora's collection of essays consists of two parts; the longer one, titled "Povertaiuchys' do Horatsiia" ("Returning to Horace"), features 12 essays on various aspects of the world and poetics of Horace, as well as on the difficulties of translating his poems (Sodomora, Studii 9-180). In this part the author includes his retranslations from Horace, i.e., new versions of his previously done translations.

8 Mykola Khvyl'ovyi (1893-1933) was a prominent Ukrainian writer and publicist, who triggered and carried forward the so-called "Literary Discussion" of the 1920s.
} 
1925, which was attended by some eight hundred people, he emphasized, among other current issues, that the Ukrainian language had to assimilate foreign lexical and grammatical forms through translation. For instance, he welcomed its potential enrichment with the forms of (1) active participle, present tense, and (2) instrumental case "ablativi auctoris" (Orest 62).

In his critical reviews, public talks, and literary essays Zerov was seeking greater rigour in verse forms, precision of expression, and clearer distinction among styles. Advocating professionalism in translating the classics, he set a high bar for his contemporaries. His own interpretations of Roman classics, however, did not strictly adhere to source text wording and fluctuated within the scope of rhymed paraphrase. To use Derzhavyn's terminology, Zerov pursued a middle course between homological and analogical translation.

In the article "U spravi virshovanoho perekladu: Notatky" ("Notes on the Case of Verse Translation"), published in the monthly Zhyttia i revoliutsiia (Life and Revolution) in 1928, Zerov was concerned with the burning questions of trends and development prospects for Ukrainian literature, and for translation as an integral part of it. The author starts with pointing out that against the backdrop of problems with contemporary original Ukrainian poetry and its declining quality, poetry in translation gained greater prominence in the late 1920s. Among successfully translated or retranslated writers with a distinctive individuality Zerov mentions Émile Verhaeren, Adam Mickiewicz, Aleksandr Pushkin, William Shakespeare, and contemporary American poets. He points to an ambitious translation project launched by Bilets'kyi and Mykola Plevako in Kharkiv, the five-volume Khrestomatiia $z$ istorii zakhidnykh literatur (Anthology of Western European Literature) from antiquity to modern times. Zerov aptly remarks that the project testifies to the high profile of Ukrainian translations of Western poetry at that time. It was also aimed at promoting new ways and modes of expression in original Ukrainian poetry. ${ }^{9}$

\footnotetext{
${ }^{9}$ Another anthology, this one of modern French poetry-edited and prepared for publication by Zerov and Stepan Savchenko in 1928-30, covering the works of numerous authors, from the Romantic Decadence era (Théophile Gautier, Gérard de Nerval) up to contemporary times-was never published. Only the volume Antychna literatura: zrazky starohrets'koi ta ryms'koi khudozhn'oi literatury (Ancient Literature: Examples from Ancient Greek and Roman Literature) of the conceived fivevolume Anthology saw the light of day. It had been ready for publication in 1935 but was delayed and published as a school textbook in 1938. It contained some of Zerov's translations, which were published anonymously because Zerov already had been executed by that time. Its publication was an act of courage on the part of both Bilets'kyi, the volume's editor, and the reviewer Mykhailo Kalynovych, who forwarded the royalties to Zerov's widow.
} 
In his brief overview of the emerging theoretical writings on issues in poetry translation, Zerov cites three Ukrainian articles: Derzhavyn's "Problema virshovanoho perekladu," Iurii Savchenko's "Pochyn," and Maifet's "Z uvah do teorii perekladu" ("From Observations Regarding Translation Theory"). Of all three critics, Zerov takes a cursory look at Maifet, commending him as a theoretician who selects illustrations for his talking points from the "present-day" Ukrainian translations of poetry, as does Derzhavyn. Zerov then refers to Savchenko's points in more detail, sharing the latter's idea of literary translation as non-identical to the source poem and striving at best for an approximate accurateness in its formal and semantic reproduction.

Zerov elaborates on the balance between verbality and musicality of the original work in translation. In his understanding of musicality as a whole aggregate of aesthetic devices that cannot be found in the dictionaries, Zerov draws on an old article by Innokentii Annenskii "Razbor stikhotvornogo perevoda 'Liricheskikh stikhotvorenii Goratsiia' P. F. Porfirova" ("Examination of the Verse Translation of 'The Lyrical Poems of Horace' by P. F. Porfirov"). ${ }^{10}$ However, his reasoning in favour of a balanced translation builds on Savchenko's viewpoint that although translation should preserve a firmly fused unity of all components of the source text that mutually refer to one another, any subordination of the whole to a single component must be avoided. In unison with Savchenko, Zerov cautions the translators of lyrical poetry against two risks-prioritizing meaning while not being able to render properly the form, or focusing on rhythmic and euphonic peculiarities of the original poem and as a result writing a new poem in the target language that is based on the given rhythmic and melodic scheme. Even though any one of these two extremes would lead the translator, likened by Zerov to a popular fairy-tale hero at the crossroads, to "death," choosing a middle way is also fraught with danger, presenting the translator with insurmountable difficulties.

The most substantive dialogue in Zerov's "Notes" is taken up with Derzhavyn, whose rigid requirements of translation Zerov both commends and criticizes. For instance, he distances himself from Derzhavyn's idea of creating a phonetic and grammatical pattern in translation that should be tantamount to the language structure of the original. Zerov anticipates that in this case the secondary, non-essential tasks and considerations may overshadow the pivotal elements of the original. In Zerov's view, these pivotal elements should prevail in the target text as the translator's primary

\footnotetext{
10 Annenskii's article was published in Saint Petersburg in 1904; it provides the groundwork for Zerov's systematic theory of verse translation, as outlined in Zerov's "Notes," together with certain other requirements set out by Derzhavyn.
}

(C) 2019 East/West: Journal of Ukrainian Studies (ewjus.com) ISSN 2292-7956

Volume VI, No. 2 (2019) 
concern, while the secondary details may be left in the shadow or even omitted.

Reassuring readers that translations must be made into our natural language, the language of our feelings, Zerov wants the target text to flow easily and smoothly, and the language to sound modern. At the same time, he firmly agrees with Derzhavyn on the point that translation should reflect the stylistic features of the original. Moreover, according to Zerov, it should simultaneously be bright, sound good, and breathe the author of the original, as opposed to a perfectly smoothed but monotonous and boring translation drill. In Zerov's viewpoint, a poet-translator with bright individuality will make more discoveries in the source text than the one who might have spent much more time on translating but whose individual profile looks featureless ("U spravi," 139). Zerov thus welcomes subjectivity in translation and gives credence to a selective approach that should be limited by the translator's sense of proportion and moderation in his/her subjectivity. Thus, he supports Annenskii's argumentation for a moderate subjectivity in translation and complements it with his own reasoning in favour of the translator's tempered subjectivity.

Temperance but not mediocrity-this is Zerov's idea of "the middle way." He stands for the translator's bright individuality as a point of departure for success, endorsed by his/her creative but not unbounded subjectivity. Defending a certain range of free movement for the translator, whom he considers as a poet and creator rather than just an adroit "literary technician," Zerov accentuates the importance of preserving in translation the substantive features of the original work (metaphors, epithets, phonetics, etc.), peculiar for every author both on the content and formal level. For Ukrainian translators who are genuinely interested in the development of the Ukrainian literary language, Zerov puts forward his recommendations a list of five desiderata.

The first desideratum concerns stylistic expressivity in translation and making stylistically appropriate lexical choices, corresponding to the style and diction of the original (Zerov, "U spravi,"141). The second desideratum points to rendering the imagery of the classical source text-first and foremost, the metaphors, metonymies, periphrases, and antonomasias. According to Zerov, the translator does not have to comply with Derzhavyn's requirement of preserving all the tropes and semantic figures of the source text, especially when they might seem strange or unnatural to the target audience. Zerov advocates here, as elsewhere, a "middle way" that favours only certain components of the source text's figurative language at the expense of less expressive ones because the translator is expected to take into account the needs of the average reader ("U spravi," 143). As an educator, university professor, and public lecturer, Zerov knew from experience the need to educate people without overloading them with 
"hard-to-digest material." That is why he warns translators against alienating the public instead of developing among readers a love of classical poetry. Having pinpointed the importance of producing a reader-friendly and likeable translation, Zerov concurrently makes it clear that he utterly agrees with Derzhavyn on the point that replacing the source text images with "a clichéd vulgarity" is unacceptable. Following in Derzhavyn's steps, he believes it intolerable to substitute hackneyed phrases for the original imagery and considers banalities "the bigger sin" against the source text's author.

The third desideratum touches upon rendering the metrical qualities of the source text. Zerov's emphasis is that the choice of metre must not be random or incidental. The metre ought to rely on the target-language speakers' feeling of poetic rhythm, while the translators' task is to strive consistently to expand the scope of this feeling. Zerov advances the idea of rendering metrical Greco-Roman verses in several possible ways, and he also stresses the importance of knowing each poem's historical background and circumstances ("U spravi," 144). The fourth desideratum concerns rendering the euphony of the source text, which includes the prosody (alliterative devices and assonances) and rhyming patterns. On this aspect, Zerov completely agrees with Derzhavyn that rhymes play the key role in the source text's euphony ("U spravi," 145).

While we are addressing the intersecting points between Derzhavyn's theory of verse translation and Zerov's list of desiderata, it is worth mentioning here a self-revisionist and literalist retranslation of Virgil's poem The Aeneid by Valerii Briusov (1873-1924), a leading poet of the Russian Symbolist movement. Zerov expresses his disapproval of Briusov's experiment with sound in his later retranslation of The Aeneid.11 As he argues, Briusov's pedantic effort to keep up with the sound of the source text made his work quite improbable for the natural Russian language and verse-though as an experiment it might be interesting for lovers of Virgil and connoisseurs of the Latin text of The Aeneid. ${ }^{12}$ Zerov rejected Briusov's philological formalism and stylistic experimentation with the translator's

11 Briusov's attitude to the act of translating evolved from initial free, fragmented renderings of Virgil's The Aeneid to more literalist later versions of the poem, of which he finished translating only seven of its twelve books. In 1933, Briusov's literalist retranslation of The Aeneid was printed in full by the Academia Publishing House in the Masterworks of World Literature series, with the remaining five books translated on the basis of Briusov's unfinished drafts by the Symbolist poet and philosophical theologian Sergei Solov'ev.

12 Briusov's latest version of The Aeneid, with close adherence to the wording and, as much as possible, to the sound of the source text turned out in many places to be incomprehensible to average readers without reference to the Latin original. 
native tongue, ironically commenting that "one can hardly recognize a translation to be ideal when the translator is only an eccentric who is immersed in sounds and stands with his face turned to the author and the source text while showing his back to the reader" ("U spravi," 146). ${ }^{13}$ Moreover, Zerov disapproved of Briusov's literalist approach both in his critical thought and in his own translation of The Aeneid. ${ }^{14}$ The few fragments of Zerov's translation of the poem that are extant were written in unrhymed dactylic hexameter.

In his fifth desideratum, Zerov points out that the beauty and, therefore, the naturalness and ease of the translator's native tongue should not be sacrificed by any means. As he argues, "only on this condition would verse translation become a staircase to higher levels of our literary and language development" ("U spravi," 146).

The above-listed desiderata show that Zerov broadly follows Horace's guidance for the original authors laid down in the "Epistle to the Pisos" concerning the unity, harmony, and proportion of a poem. Zerov requires such appropriateness of the metre, style, and diction to the subject matter in translation, as Horace required in the original poem. The Horatian advice for translators to invent a new expression and recreate boldly also resonates in Zerov's "Notes." Moreover, it is well put to use in his own Russian translation of the Epistle, "Poslanie k pizonam-Ob iskusstve poezii" ("Epistle to the Pisos-On the Art of Poetry") written in 1935 (after Zerov moved from Kyiv to Moscow, hoping to escape impending arrest by the Soviet secret police ${ }^{15}$ ) and published anonymously in the anthology Rimskaia literatura (Roman Literature) (Kondrat'ev; reprinted in Zerov, Tvory 476-87). Zerov's new version of the Horatian "Epistle to the Pisos" was intended to replace the translation by Afanasii Fet (printed as early as 1883), which in the 1930s

13 Unless otherwise indicated, all translations in this article are my own.

14 Zerov treated his own work on the first full-length translation of The Aeneid with a special responsibility, seeing it as his greatest service to future generations. The majority of Zerov's translation legacy was lost forever, along with the manuscript of the entire translation of Virgil's poem. Zerov's letters to his wife, the last of which was dated 19 September 1937, while he was imprisoned in the Solovetsky Islands of the GULAG, show that he had managed to complete his long-term project of translating the entire Aeneid before he was executed in early November. It has been observed that Zerov never parted with a small volume of Virgil, even at Solovki, and was executed with the book in his coat pocket (according to the narratives told by surviving fellow convicts).

15 One of the leading literary figures of the Ukrainian cultural revival, Zerov was ultimately arrested, convicted, and sent to the Soviet concentration camp in the Solovetsky Islands. On 3 November 1937, he was executed by firing squad in a forest at Sandarmokh, Karelia, along with many other eminent personalities of the Executed Rennaissance.

(C) 2019 East/West: Journal of Ukrainian Studies (ewjus.com) ISSN 2292-7956

Volume VI, No. 2 (2019) 
was considered-not unreasonably-rather outdated lexically and stylistically, ${ }^{16}$ and was fated to yield to a more accurate translation.

In his translation of the Epistle into Russian, Zerov consciously distances himself from the imperial Russian tradition of retelling the classics, with its implicit ideal of mediocrity. The readers of translated poems are bound to remain simply readers and not co-creators if the translator retells the original author's works outside the context of his/her imaginative world and poetics-as Fet generally did with the Horatian odes. Zerov reconfigures Fet's interpretation of Horace's principal aesthetic concepts. Broadly speaking, the "golden mean," simply understood as happiness with a modest life, became generally interpreted as "golden mediocrity," or ordinariness, in the nineteenth-century Russian literary tradition. But Zerov unobtrusively opposed his own and more profound interpretation of this important notion to its utilitarian, down-to-earth implications patterned by the Russian literary tradition, which had heretofore been an invariant model for the imperial peripheries to emulate.

It is noteworthy, thus, that Zerov not only made use of the Russian tradition of translating Horace as an illustration for his desiderata, but he also challenged this tradition by contributing his own translation of the Epistle to it. In comparison with the version of the poem by Fet, who tended to simplify Horace's lively diction and thought (style), Zerov was able to keep up stylistically with the witty ingenuity and intellectual superiority of the Epistle's speaker. Undemonstrably but clearly enough, Zerov competes with Fet and counters his otiose and fallacious tendency of debasing the style and simplifying the Horatian thought. Even a cursory examination of Zerov's translation is enough to confirm that he elaborates expressive forms more successfully and makes the diction more specific and eloquent, than does Fet.

To illustrate this point further, Table 2 offers a famous quotation from Horace's "Epistle to the Pisos" (lines 131-35) about the task of the true artist versus the task of the "faithful" (in Horace it equals "slavish") translator-in the Latin original (see The Art of Poetry) and in Russian translations by Fet and Zerov (Tvory 479).

\footnotetext{
16 In his translation of The Epistle, Fet popularized Horace for the general Russian reader, having contributed to the tradition of retelling the classics, and in particular to the utilitarian adaptation of Horace's ideas of the "useful" and the "pleasant," together with the common perception of the "golden mean" as "golden mediocrity."
} 
Table 2. Lines 131-35 from Horace's "Epistle to the Pisos" in the Latin original and translations into Russian by Fet and Zerov.

\begin{tabular}{|c|c|c|}
\hline Line 131 & Horace (Lat) & $\begin{array}{l}\text { Publica materies privati } \\
\text { juris erit, si }\end{array}$ \\
\hline & Fet (Russian) & $\begin{array}{l}\text { Общеизвестный } \\
\text { предмет твоим } \\
\text { достоянием станет }\end{array}$ \\
\hline & Zerov (Russian) & $\begin{array}{l}\text { Общественное станет } \\
\text { тогда лишь твоим } \\
\text { достоянием, если }\end{array}$ \\
\hline \multirow[t]{3}{*}{ Line 132} & Horace (Lat) & $\begin{array}{l}\text { Non circa vilem } \\
\text { patulumque moraberis } \\
\text { orbem; }\end{array}$ \\
\hline & Fet (Russian) & $\begin{array}{l}\text { Если в пошлом и } \\
\text { низком кругу не } \\
\text { будешь вращаться; }\end{array}$ \\
\hline & Zerov (Russian) & $\begin{array}{l}\text { Ты не захочешь в } \\
\text { затоптанном, пошлом } \\
\text { кругу оставаться, }\end{array}$ \\
\hline \multirow[t]{3}{*}{ Line 133} & Horace (Lat) & $\begin{array}{l}\text { Nec verbum verbo } \\
\text { curabis reddere, fidus }\end{array}$ \\
\hline & Fet (Russian) & $\begin{array}{l}\text { Ежели, как переводчик, } \\
\text { не станешь ты слово за } \\
\text { словом }\end{array}$ \\
\hline & Zerov (Russian) & $\begin{array}{l}\text { Не пожелаешь, как } \\
\text { робкий толмач, от } \\
\text { слова до слова }\end{array}$ \\
\hline \multirow[t]{3}{*}{ Line 134} & Horace (Lat) & $\begin{array}{l}\text { Interpres; nec desilies } \\
\text { imitator in arctum, }\end{array}$ \\
\hline & Fet (Russian) & $\begin{array}{l}\text { Передавать и не } \\
\text { влезешь в такую } \\
\text { трущобу, откуда }\end{array}$ \\
\hline & Zerov (Russian) & $\begin{array}{l}\text { Свой повторять } \\
\text { образец, пока не } \\
\text { завязнешь с ногами }\end{array}$ \\
\hline
\end{tabular}

(c) 2019 East/West: Journal of Ukrainian Studies (ewjus.com) ISSN 2292-7956

Volume VI, No. 2 (2019) 
Table 2. Cont.

\begin{tabular}{|l|l|l|}
\hline Line 135 & Horace (Lat) & $\begin{array}{l}\text { Unde pedem proferre } \\
\text { pudor vetet aut operis } \\
\text { lex. }\end{array}$ \\
\hline & Fet (Russian) & $\begin{array}{l}\text { Вытащить ног или } \\
\text { стыд не позволит, иль } \\
\text { смысл сочиненья. }\end{array}$ \\
\hline Zerov (Russian) & $\begin{array}{l}\text { В той тесноте } \\
\text { подражанья, что шагу } \\
\text { ступить не позволит. }\end{array}$ \\
\hline
\end{tabular}

Zerov's diction is more abstract and literarily more polished than Fet's vocabulary and phrasing, e.g., "obshchestvennyi predmet" (Fet) vs. "obshchestvennoe" (Zerov). Although less verbatim, Zerov's translation is more refined idiomatically, having overcome the flavour of ordinariness and lack of any elevation in Fet's style. Using paraphrases, Zerov heightens the overall diction of the Epistle compared to Fet, who tends to use common idioms and pedestrian vocabulary, so that eventually the ancient Roman orator's diction sounds as a set of banalities, e.g., " $v[. .$.$] nizkom krugu" (Fet)$ vs. "v zatoptannom [...] krugu" (Zerov); "v [...] krugu [...] vrashchat'sia" (Fet) vs. " $v[\ldots]$ krugu ostavat'sia" (Zerov); "ne vlezesh'v takuiu trushchobu" (Fet) vs. "ne zaviaznesh' s nogami" (Zerov); "vytashchit' nog" (Fet) vs. "shagu stupit"' (Zerov), etc. Meanwhile, Zerov departs from the source text wording and yet arrives at the desired destination: he comes closer to the original intention. The most telling example from the above quotations is the word combination "fidus interpres" with the adjective "fidus" ("faithful"), which is overlooked in Fet and rendered by Zerov as "robkii" ("timid," "shy"). The attributive meaning of the phrase "robkii tolmach" ("timid/humble interpreter") connotes in Zerov with the Horatian concept of "fidus interpres" ("faithful translator") as a slavish imitator.

Thus, Zerov's approach to paraphrasing the classics does not follow in the steps of the Russian tradition as such, with its implicit ideal of "mediocrity," and still less does it adhere specifically to Fet. Rather, his maxims are based on recognition of the highly important role of translated literature for the development of the Ukrainian literary language, which had been disadvantaged and banned from the field of translation in the Russian Empire, and supported only hypocritically and briefly by the Bolsheviks in the 1920s (Pauly).

As a poet-translator and translation critic, Zerov brought his readers' attention to the rigour and clarity of thought in translation, and to the 
importance of exact and coherent rendering of the ideas found in classical authors' works-but not of separate words or distorted meanings of the source text. Zerov filled the gaps in the theory and practice of Ukrainian verse translation, which had to make significant strides to overcome its colonial inferiority, and he availed himself of the best theoretical sources he could find for this purpose and recommended them to his readers.

Within the context of Zerov's reformatory role in the craft of translation, reference should be made to the far-reaching influence of his lessons on succeeding generations. As summarized by distinguished Ukrainian poettranslator Dmytro Pavlychko in 1989:

Zerov the translator is a pioneer of the new translation tradition in our literature. And it's to him that we owe our groundbreaking success in this field. In this respect, all of us are his followers and disciples: both those who worked beside him and those who can experience his presence, for example, in the arduous translation toils of Andrii Sodomora. (18)

The above words from Pavlychko's introductory essay, titled "Bezsmertnyi maister" ("The Immortal Master"), to the first volume of Zerov's collected works might sound rather lofty but are not untrue in relation to the leading Ukrainian translators of the mid- and late twentieth century, including Sodomora.

\section{RETHINKING HORACE IN THE WORKS OF ANDRII SODOMORA: "AUREA MEDIOCRITAS" AS EXCEPTIONALITY}

A member of the Zerov school of translation, Andrii Sodomora's contributions to Ukrainian literature include a complete collection of the works of Horace (1982), Ovid's narrative poem "Metamorphoses," an epic philosophical poem by Lucretius titled "De rerum natura" ("On the Nature of Things"), and a diverse selection of Roman poetry from antiquity, among other classics. But unlike Zerov, Sodomora gradually shifted, through revising his previous translations, to a (neo)literalist strategy.

In contrast to Zerov, whose attitude to translating the Roman classics demonstrated that the main purpose of the translator was to render the overall integrity of a literary work, Sodomora tends to consider his translations from the literature of antiquity as being akin to extensive quotations from a different mentality and world view of another culture. In Sodomora's opinion, generally expressed in The Study of a Single Poem, there is nothing minor, secondary, or non-essential in classical texts such as the works of Horace, where the precision of expression constitutes a distinguishing stylistic feature; and that, in turn, makes the classification of 
lexemes in the classics like Horace into major and minor ones a completely futile endeavour. Sodomora's new approach to translating the classics reconsiders a number of previously done translations, including the one of The Aeneid by Mykhailo Bilyk, ${ }^{17}$ and establishes a revisionist criticism of paraphrasing and embellishing translations that had been based on the strategy of rewriting the originals-even if this strategy was represented by such an iconic figure in the twentieth-century Ukrainian literature as Zerov.

A post-Soviet rereading of the classics tends to demonstrate that poetry does not necessarily need to be aimed at broad audiences. Horace is a good example of a poet who addresses his works to a rather narrow circle of connoisseurs and venerators of poetry whom he considered the co-creators of his poetic texts. And, respectively, translations should give contemporary readers a taste of the subtleties of Horatian poetics. This taste can be found in Sodomora's retranslating strategy and his reconsideration of the concept of the "golden mean" ("aurea mediocritas") as a combination of such seemingly incongruous elements as poeticality and precision. In particular, Sodomora speaks about the overall semantic accuracy and geometric precision in Horace, and seeks an appropriate place, a point ("punctum"), for every word in the text. From Sodomora's perspective, Horace demonstrates that the poet has to say as much as necessary, no more and no less; has to keep to the golden mean, or to the middle, because "in the middle his poetic speech is exact and clear, but from both sides of the middle it is misty and vague" (Studii 56).

How Horace's rule of the golden mean works structurally (rhythms, rhymes, alliterations, and assonances) is well demonstrated by Sodomora in The Study of a Single Poem, as well as in samples of his self-revisionist retranslations included in the book. ${ }^{18}$ Unlike Zerov-the father of the Ukrainian canon of Roman classics, in whose artistic picture of the classical world "aurea mediocritas" was related to temperance-Sodomora associates the concept of "aurea mediocritas" in poetry with exceptionality. For him, the antiquity of Horace consists in the novelty of his poetic creations

\footnotetext{
${ }^{17}$ It does not satisfy Sodomora because of Bilyk's persistent use of monotonous and unnatural dactylic rhythms and his dogmatic refusal to diversify them with spondees (Studii 31).

18 In the samples of his retranslations of Horatian odes published in the volume, Sodomora himself practically joins the camp of literalist translators such as Briusov, insisting that concreteness and specificity of expression constitute the distinguishing features of Horace's style, which makes it impossible for the translator to prioritize certain words in the source text to the detriment of others. Arguing with Zerov's view of Horace, Sodomora tries in his own way to show Horace as an undetached and emotional poet of harmony.
} 
for his contemporaries as well as the freshness of his imagery and the relevance of discussed topics to contemporary life.

Sodomora observes that free and rhymed translations of the classics, which are oriented at an average general reader, lack "otherness" (Studii 36). He warns that the metre in translation should not only be a regular metrical pattern, it should also constitute the pulse of a lyrical work. And the critics should be concerned not so much with the "spirit" of the poetic source text and an abstract faithfulness to it as with the genuine rhythmical pulsation of the poem and the translator's accurateness in rendering it. Not without reason, then, Zerov's translations of Horace are predominantly qualified by Sodomora as "free renderings" (Studii 68).

Retrospectively, unlike his strategic opponent Zerov-for whom the Horatian rule of harmony was synonymous with temperance, and whose masterful but oftentimes unbounded rhyming translations departed from the source text wording because of the translator's primary purport to render the overall integrity of a poem-Sodomora consciously seeks an alienating effect in translation, trying to represent Horace as an undetached and emotional poet of harmony rather than a cold Parnassian.

The tension between rhymed paraphrases and the struggle to keep the word order of the source text can be well illustrated by Zerov's "syllabotonic" translation of the "Ode to Melpomene," given in the second section of this essay. In his critical commentaries on Zerov's version of the Ode, set forth in the essay "Zelene kreshchendo Horatsiievoho 'Pam"iatnyka': tin' zhyva-i tin' vichna" ("The Green Crescendo of Horace's 'Monument': A Shadow Alive and a Shadow Eternal"), Sodomora tries to prove that a great deal of the original intention will be lost when an ancient text is translated from the metrical into the syllabo-tonic system of versification, and even more so if the translator uses rhymed verse for this purpose (Studii 11-41). Sodomora's own alignment to the Horatian geometric precision is reflected in these two translation versions-from the 1982 edition (89-90) and the 2006 edition (33), given below in Table 3. Alongside Sodomora's texts are my interlinear translations (identical passages in both versions are underlined). 
Table 3. Sodomora's translations of the "Ode to Melpomene" from the 1982 and 2006 editions, accompanied by my interlinear translation of both versions.

\begin{tabular}{|c|c|}
\hline “Do Mel'pomeny” (1982) & “Do Mel'pomeny" (2006) \\
\hline $\begin{array}{l}1 \text { Звів я пам'ятник свій. Довше, ніж } \\
\text { мідь дзвінка, } \\
\text { I have erected my own monument. } \\
\text { Longer than clinking brass, }\end{array}$ & $\begin{array}{l}1 \text { Звів я пам'ятник: він - } \\
\text { перетриває мідь, } \\
\text { I have erected a monument: it will } \\
\text { outlast brass, }\end{array}$ \\
\hline $\begin{array}{l}2 \text { Вищий од пірамід царських, } \\
\text { просто́їть він. } \\
\text { Higher than the royal pyramids it will } \\
\text { remain and last. }\end{array}$ & $\begin{array}{l}2 \text { Над верхи пірамід гінко } \\
\text { зіпнеться він. } \\
\text { Over the tops of the pyramids it will } \\
\text { quickly rise. }\end{array}$ \\
\hline $\begin{array}{l}3 \text { Дощ його не роз'їсть, не сколихне } \\
\text { взимі, } \\
\text { Neither rain will corrode it, nor Aquilon } \\
\text { shake it in winter, }\end{array}$ & $\begin{array}{l}3 \text { Дощ його не роз'їсть і не змете } \\
\text { його, } \\
\text { Neither rain will corrode it, nor } \\
\text { Aquilon sweep it away, }\end{array}$ \\
\hline $\begin{array}{l}4 \text { Впавши в лють, Аквілон; низка } \\
\text { років стрімких - } \\
\text { Having succumbed to rage: a caravan of } \\
\text { swift years - }\end{array}$ & $\begin{array}{l}4 \text { Впавши в лють, Аквілон; ліку не } \\
\text { знаючих } \\
\text { Having succumbed to rage: the pace } \\
\text { of innumerable }\end{array}$ \\
\hline $\begin{array}{l}5 \text { Часу біг коловий - в прах не зітре } \\
\text { його. } \\
\text { A circular flight of time - will not reduce } \\
\text { it to dust. }\end{array}$ & $\begin{array}{l}5 \text { Років крок не зітре - весен і зим } \\
\text { розгін. } \\
\text { Years will not wipe it out - the rush } \\
\text { of springs and winters. }\end{array}$ \\
\hline $\begin{array}{l}6 \text { Смерті весь не скорюсь: не западе в } \\
\text { імлу } \\
\text { Not all of me will surrender to death: } \\
\text { the best part of me }\end{array}$ & $\begin{array}{l}6 \mathrm{Hi}, \text { не весь я умру - більша єства } \\
\text { мого } \\
\text { No, not all of me will die - a bigger } \\
\text { part of my nature }\end{array}$ \\
\hline $\begin{array}{l}7 \text { Частка краща моя. Поміж } \\
\text { потомками } \\
\text { Will not vanish into the mist. Among } \\
\text { descendants }\end{array}$ & $\begin{array}{l}7 \text { Частка смерть омине: у похвалі } \\
\text { живій } \\
\text { Will avoid death: in living praise }\end{array}$ \\
\hline $\begin{array}{l}8 \text { Буду в славі цвісти, поки } 3 \\
\text { Весталкою } \\
\text { I shall bloom in glory, as long as the } \\
\text { pontiff-priest }\end{array}$ & $\begin{array}{l}8 \text { Я вростатиму в час, поки } 3 \\
\text { Весталкою } \\
\text { I will grow into the time, as long as } \\
\text { the pontiff-priest }\end{array}$ \\
\hline
\end{tabular}


Table 3. Cont.

\begin{tabular}{|c|c|}
\hline “Do Mel'pomeny” (1982) & “Do Mel'pomeny” (2006) \\
\hline $\begin{array}{l}9 \text { Йтиме понтифік-жрець до } \\
\text { Капітолію. } \\
\text { Will tread to the Capitol with a Vestal. }\end{array}$ & $\begin{array}{l}9 \text { Буде понтифік-жрець на Капітолій } \\
\text { йти, - } \\
\text { Will ascend the Capitol with a Vestal. }\end{array}$ \\
\hline $\begin{array}{l}10 \text { Там, де Авфід бурлить, де } \\
\text { рільникам колись } \\
\text { Over there, where the Aufidus churns, } \\
\text { where Daunus }\end{array}$ & $\begin{array}{l}10 \text { Там, де Авфід бурлить, де орачам } \\
\text { колись } \\
\text { Over there, where the Aufidus churns, } \\
\text { where Daunus }\end{array}$ \\
\hline $\begin{array}{l}11 \text { Давн за владаря був серед полів } \\
\text { сухих - } \\
\text { Once ruled over the plowmen in dry } \\
\text { fields, }\end{array}$ & $\begin{array}{l}11 \text { Давн за владаря був серед полів } \\
\text { сухих, - } \\
\text { Once ruled over the plowmen in dry } \\
\text { fields, }\end{array}$ \\
\hline $\begin{array}{l}12 \text { Будуть знати, що я - славний } 3 \\
\text { убогого - } \\
\text { People will know that I - glorious from } \\
\text { the poor - }\end{array}$ & $\begin{array}{l}12 \text { Мова йтиме, що я - славний } 3 \\
\text { убогого - } \\
\text { People will say that I - glorious from } \\
\text { the poor - }\end{array}$ \\
\hline $\begin{array}{l}13 \text { Вперше скласти зумів по- } \\
\text { iталійському } \\
\text { For the first time, managed to compose } \\
\text { Aeolian songs }\end{array}$ & $\begin{array}{l}13 \text { Вперше скласти зумів н } \\
\text { італійський лад } \\
\text { For the first time, managed to compose } \\
\text { Aeolian songs }\end{array}$ \\
\hline $\begin{array}{l}14 \text { Еолійські пісні. Горда по праву } \\
\text { будь, } \\
\text { In the Italian language. Be rightfully } \\
\text { proud, }\end{array}$ & $\begin{array}{l}14 \text { Еолійські пісні. Горда - й } \\
\text { заслужено - } \\
\text { In Italian style. Proud - and justly - }\end{array}$ \\
\hline $\begin{array}{l}15 \text { Мельпомено, й звінчай, мило } \\
\text { всміхаючись, } \\
0 \text { Melpomene, and with a charming } \\
\text { smile, }\end{array}$ & $\begin{array}{l}15 \text { Зі здобутків таких, лавром із } \\
\text { Дельф мені, } \\
\text { Of such achievements, with a laurel } \\
\text { from Delphi, }\end{array}$ \\
\hline $\begin{array}{l}16 \text { Лавром сонячних Дельф нині й } \\
\text { моє чоло. } \\
\text { Put a laurel from the sunny Delphi now } \\
\text { on my forehead, too. }\end{array}$ & $\begin{array}{l}16 \text { Мельпомено, чоло ти залюбки } \\
\text { вповий. } \\
0 \text { Melpomene, my forehead willingly } \\
\text { crown. }\end{array}$ \\
\hline
\end{tabular}


Both versions of the poem by Sodomora - the earlier and the later one-are unrhymed and strive to reproduce the ancient metrical verse by means of the syllabo-tonic system as accurately as possible. The later translation is nevertheless closer to the source text word order, though its multiple inversions make it sound alien to the Ukrainian ear. The inversion as a specific means of emphasis characterizes the works of ancient Roman poets, whose contemporaries (accustomed to oral poetry) easily perceived the harmony of their inverted diction. Sodomora's retranslations of Horace aim at preserving the original inversion to the utmost extent.

Since the inverted word order is not fully reflected in my interlinear English representation of Sodomora's work in the above-given table, I will further point to the most vivid examples of inversion and the development of this stylistic device in Sodomora, who strictly follows the first Asclepiadean verse pattern in his two versions of the "Ode to Melpomene." His only, and acceptable, modulation of the source text metre consists in unification of the anceps syllables ${ }^{19}$ of the pattern ŪŨ|ŪUUŪ||ŪUUŪ|UŨ. In Sodomora, the first anceps in the line stays unstressed and the second anceps is stressed almost everywhere. Accordingly, the first foot becomes consistently trochaic and the last one iambic, with two choriambs inbetween and a diaeresis in the middle of the line: ÚU|ÚUUÚ||ÚUUÚ|UÚ.

Ukrainian readers can thus experience an equivalent effect of the Asclepiadean verse form, regardless of how alien its lyrical pulse sounds to the Ukrainian ear. Although devoid of rhymes, the Horatian verse acquires in Sodomora the intended lightness of its metrical pace. Another feature we remark upon is the semantic content of the Ode in Sodomora, different from its version in Zerov, which is recognizable and "classically" familiar to the Ukrainian ear. However, Sodomora keeps the two distinctly exalted lexemes introduced in Zerov's text of the Ode, and brings them into play anew: "iestvo" ("essence") in the second version- "bil'sha iestva moho chastka" ("a bigger part of my nature") - and "cholo" ("forehead") in both versions"lavrom soniachnykh Del'f nyni i moie cholo" ("put a laurel from sunny Delphi on my forehead, too") and "Mel'pomeno, cholo ty zaliubky vpovyi" ("O Melpomene, my forehead willingly crown").

Having returned the "Ode to Melpomene" to its initial rhythmical structure, Sodomora digs into the subtext and brings to the surface some of the author's implications, especially in the second version. In the phrase "hinko zipnet'sia vin" ("it will quickly rise"), for instance, he introduces an expansion of the original meaning, drawing a parallel with the image of a tree, which symbolizes endurance and glory. Amplification of the original

\footnotetext{
${ }^{19}$ In the Latin art of versification, an anceps syllable (Ũ) could be either short or long, depending on the type of metrical line. In the syllabo-tonic versification, it may turn into either a stressed or unstressed syllable.
} 
meaning of the North Wind's epithet ("Aquilo impotens"), whose temper is so powerful that it cannot get control over itself, is traceable in the phrase "vpavshy $v$ liut"' ("having succumbed to rage"). Metaphorization of the original idiom "annorum series" is introduced by the alliterated locution "rokiv krok" ("the pace of years") in order to accentuate the sound image of steps. Periphrasis "vesen i zym rozghin" ("the rush of springs and winters") in place of the original idiom "fuga temporum" alludes to the alternation of green and white, colours that constitute a notable and effective contrast in Horace. Metonymic modulation of the phrase "usque ego postera"- " $u$ pokhvali zhyvii" ("in living praise")-leads to the translator's neologistic metaphor "vrostatymu $v$ chas" ("I will grow into the time"), which compensates for the exceptionally emotional, imaginative, and philosophical density of the multi-layered idiom central to the poem, "crescam laude recens."

Frugality and careful calculation in the use of words feature in Sodomora's translation strategy. Rigorous and insistent on applying the standard of the ancient metre, he is highly selective in striving to ensure aphoristic brevity, uniqueness, and freshness for the Horatian idioms in his new (but never final) versions. For instance, in place of Zerov's common phrase "prostykh syn bat'kiv" ("son of low-born parents") for the laconic original "ex humili potens" he produces a succinct, Horatian-style saying"slavnyi z ubohoho" ("glorious from the poor")—-which sounds strange to the Ukrainian ear.

His syntactic estrangement is more intense in the latter version of the poem, published in The Study of a Single Poem. Below I will illustrate the tendency to estrangement with two examples of parallel excerpts from both versions, belonging to the 1982 and 2006 editions, respectively. The latter version demonstrates a higher density of alienating positions for various parts of the sentence, uncommon for the Ukrainian syntax (underlined).

\section{Example 1}

In the earlier version: "nyzka rokiv strimkykh - / Chasu bih kolovyi - v prakh ne zitre ioho" ("a caravan of swift years - / A circular flight of time will not reduce it to dust").

In the later version: "liku ne znaiuchykh / Rokiv krok ne zitre - vesen $i$ zym rozghin" " the pace of innumerable / Years will not wipe it out - the rush of springs and winters").

An alienating effect is obtained here from the unusual word order: (1) prepositional placement of the attributive word combination liku ne znaiuchykh / Rokiv, which is a heterogenous attribute of the noun krok; and (2) isolated position of the nominal predicate vesen i zym rozghin. 


\section{Example 2}

In the earlier version: "Horda po pravu bud', / Mel'pomeno, i zvinchai, mylo vsmikhaiuchys', / Lavrom soniachnykh Del'f nyni i moie cholo" ("Be rightfully proud, / O Melpomene, and with a charming smile, / Put a laurel from the sunny Delphi now on my forehead, too").

In the later version: "Horda - i zasluzheno - / Zi zdobutkiv takykh, lavrom iz Del'f meni, / Mel'pomeno, cholo ty zaliubky vpovyi" ("Proud - and justly - / Of such achievements, with a laurel from Delphi, / O Melpomene, my forehead willingly crown").

Here, a natural word order would have been as follows: "Mel'pomeno, horda zi zdobutkiv takykh - i zasluzheno, - ty vpovyi zaliubky meni cholo lavrom iz Del'f," with both the attributive word combination and the instrumental direct object in postposition. Instead, the prepositional phrase "Horda - i zasluzheno - / Zi zdobutkiv takykh," which is a heterogeneous attribute of the vocative noun Mel'pomeno, incorporates an isolated adverbial modifier " $i$ zasluzheno." Moreover, it is detached from the attributed word by the phrase "lavrom iz Del'f meni," which is an instrumental direct object of the verb "vpovyi," prepositioned to it.

The above examples demonstrate that Sodomora is seeking an alienating effect, but without extremes, always keeping in mind the Horatian rule of harmony, or the "golden mean," by which Zerov, a staunch proponent of "the art of equilibrium," was also guided. Nevertheless, Sodomora's focus on "golden mean" as exceptionality fundamentally differs from Zerov's understanding of the Horatian rule of harmony as temperance. Sodomora's reinterpretation of Horace, thus, represents an important achievement and yet another milestone along the path towards a better understanding and more vivid reproduction of the ancient world, with its complex sociocultural values.

However, no matter how close Sodomora's later translation of the "Ode to Melpomene" appears to come to the original wording, when juxtaposed side-by-side with the source text, it is still not a word-for-word mirrored reflection of it. As a translator, Sodomora produces cohesive texts, with each rewording being justified by improved clarity of meaning. He regards Horatian odes as extremely intense and economical, entirely composed of key words, and consequently, he avoids unmotivated and remote paraphrases, looking instead for the emotional kernel of each Horatian word.

In his essay "Neskhytnyi dukh nad urvyshchem zhyttia" ("Unwavering Spirit Above the Chasm of Life"), Sodomora pinpoints Horace's creed to speak not only intently, in a focused manner ("intente"), but also succinctly ("expresse"-from "exprimere" "to imprint, impress"), with the maximal extraction from the word of all its possible expressiveness (Studii 58). And since the word displays its expressive potential in interacting with other 
words, Sodomora prefers inversion-a favourite Horatian device-to align the words in such an order that each one reveals its hidden affinities. Juxtaposing accentuated words, his retranslations convey the contours of visual images that are not immediately noticeable. Inversion thus helps to put readers on track. It positionally emphasizes the most essential words, and conditions their interaction by bringing them together or, vice versa, separating them and putting them at the opposite ends of a poetic line, or even in different lines.

To illustrate the economy of Sodomora's retranslating strategy, below in Table 4, in the left-hand column I suggest for consideration the first stanza from the "Ode to Dellius," (Horace, Ode 2.3)-Horace's address to his younger friend Dellius, in which Horace develops his motto "carpe diem" ("seize the day"), formulated in Ode 11 from Book I (Ode 1.11). And in the right-hand column, I provide the metrical translation of this stanza by Kline.

Table 4. The first stanza from the "Ode to Dellius" in Latin original (lefthand column) and its metrical English translation (right-hand column).

\begin{tabular}{|l|l|}
\hline $\begin{array}{l}\text { First stanza from the “Ode to } \\
\text { Dellius" (Horace, Ode 2.3) }\end{array}$ & $\begin{array}{l}\text { Metrical translation by Kline (The } \\
\text { Odes: Book In }\end{array}$ \\
\hline 1 Aequam memento rebus in arduis & $\begin{array}{l}\text { When things are troublesome, always } \\
\text { remember, } \\
2 \text { servare mentem, non secus in bonis } \\
\text { keep an even mind, and in prosperity } \\
\text { ab insolenti temperatam }\end{array}$ \\
betitia, moriture Delli, & since my Dellius, you're destined to die, \\
\hline
\end{tabular}

Alongside an array of other poetic forms, Horace created and introduced into the Roman poetry a new stanzaic model, having combined a variety of Alcaic metres into his own pattern of the Alcaic strophe. "Ode to Dellius" embodies this particular kind of the Aeolic verse form, known as the Horatian Alcaic strophe.

The Alcaic strophe in Horace consists of four lines, with the following number of syllables most commonly employed in each line: 11 (5 long +6 short) twice, 9, and 10. Below, in Table 5, a standard scheme of the Alcaic strophe (left column) is given in comparison with its Horatian version (right column), where the first anceps syllable and the fifth anceps syllable of the first three lines are long. 
Table 5. A standard scheme of the Alcaic strophe (left-hand column) in comparison with its Horatian version (right-hand column).

\begin{tabular}{|c|c|}
\hline Standard Latin Alcaic Strophe & Horatian Alcaic Strophe \\
\hline 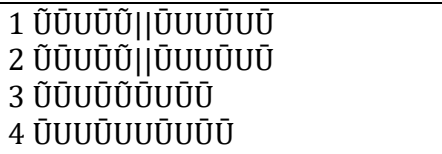 & 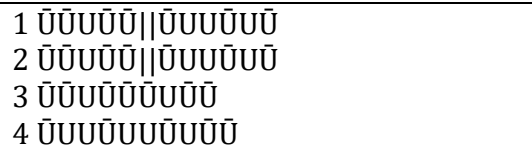 \\
\hline \multicolumn{2}{|c|}{$\begin{array}{l}\text { A "Ũ" denotes an anceps syllable, "Ü" a long syllable, "U" a short one, and "II" is the } \\
\text { caesura. }\end{array}$} \\
\hline
\end{tabular}

Zerov transforms the Alcaic strophe of this Ode into iambic stanzas ("Do Delliia," Tvory 289-90). Specifically, he resorts to iambic hexameter in lines 1-3, with an extra unaccented syllable, or the seventh truncated foot, in the first and third lines, and iambic tetrameter in line 4. The third foot in lines 13 and the second foot in line 4 are pyrrhic (with both syllables unaccented). The total number of stressed syllables is thus five in lines 1-3 and three in line 4 . The number of syllables per line in each stanza is 13-12-13-8. The use of caesuras breaks up the iambic rhythm in the middle of lines 1-3 of each stanza, except for line 3 of the first stanza, where the rhythm follows the intonational pattern (with a pause after the first foot). The caesura helps the verse sound closer to natural speech, and Zerov effectively applies rhetorical pauses in the proper places, so that they make the poetic diction sound like natural speech. At the same time, Zerov's rigid adherence to the unified metrical pattern necessitates a one-syllable-forward displacement of the natural lexical stress in such words as "strymáty" (should be "strýmaty"), "hriznómu" (should be "hríznomu"), and "cherhý" (should be "chérhy").

Zerov's verse pattern in the first stanza of the "Ode to Dellius" is shown schematically in Table 6 below (left-hand column), exemplified by my interlinear translation (right-hand column) (Tvory 289). 
Table 6. The metrical pattern of Zerov's verse in the first stanza of the "Ode to Dellius" (left-hand column), exemplified by my interlinear translation (right-hand column).

\begin{tabular}{|c|c|}
\hline $\begin{array}{l}\text { Zerov's verse pattern in the first } \\
\text { stanza of the "Ode to Dellius" }\end{array}$ & $\begin{array}{l}\text { Zerov's version of the first stanza of } \\
\text { the "Ode to Dellius" ("Do Delliia," } \\
\text { Tvory 289) in my interlinear } \\
\text { translation }\end{array}$ \\
\hline 1 UÚ|UÚ|UU||UÚ|UÚ|UÚ|U|| & $\begin{array}{l}1 \text { В години розпачу умій себе } \\
\text { стрима́ти, } \\
\text { In hours of despair be able to restrain } \\
\text { yourself, }\end{array}$ \\
\hline 2 UÚ|UÚ|UU||UÚ|UÚ|UÚ|| & $\begin{array}{l}2 \text { I в хвилі радості заховуй супокій, } \\
\text { And in a moment of joy remain calm, }\end{array}$ \\
\hline 3 UÚ||UÚ|UU|UÚ|UÚ|UÚ|U|| & $\begin{array}{l}3 \text { I знай: однаково прийдеться } \\
\text { умирати, } \\
\text { And know that either way you're going } \\
\text { to have to die, }\end{array}$ \\
\hline 4 UÚ|UU|UÚ|UÚ & $\begin{array}{l}4 \text { O Деллію коханий мій, } \\
\text { O Dellius, my sweet one, }\end{array}$ \\
\hline \multicolumn{2}{|c|}{$\begin{array}{l}\text { A "Ú" denotes an accented syllable, "U" an unaccented one, "I" a foot boundary, and } \\
\text { "II" is the caesura }\end{array}$} \\
\hline
\end{tabular}

Zerov's aphorism "Odnakovo pryidet'sia umyraty, o Delliiu kokhanyi mii!" (lines 3-4), based on the Horatian idiom "moriture Delli," became a proverbial catchphrase in the modern Ukrainian language. And because of its popularity, any new attempt at translating the Ode carries risks for the translator who seeks acclaim.

Sodomora took a radical turn and launched an unpopular literalist approach to Horatian verse, which is nevertheless stylistically more equivalent to the source text than the strategy of fluent paraphrase for the general public that was professed by Zerov. Contrary to Zerov's practice, Sodomora strives for the greatest accuracy in reproducing the authentic rhythmical orality of the Ode and its unusual cadence. In his earlier edition he reproduces as close as possible the Latin Alcaic stanza, keeping unstressed the first and fifth anceps syllables of the first three lines, which may be long or short in the Latin verse, though in Horace they are normally long (Sodomora, Kvint 46). Table 7 schematically illustrates Sodomora's verse in the first stanza of the "Ode to Dellius" (left-hand column), and in 
parallel to the metrical pattern, it suggests English transliteration and my interlinear translation of Sodomora's version (right-hand column).

Table 7. The 1982 metrical pattern of Sodomora's verse in the first stanza of the "Ode to Dellius" (left-hand column), exemplified by my interlinear translation (right-hand column).

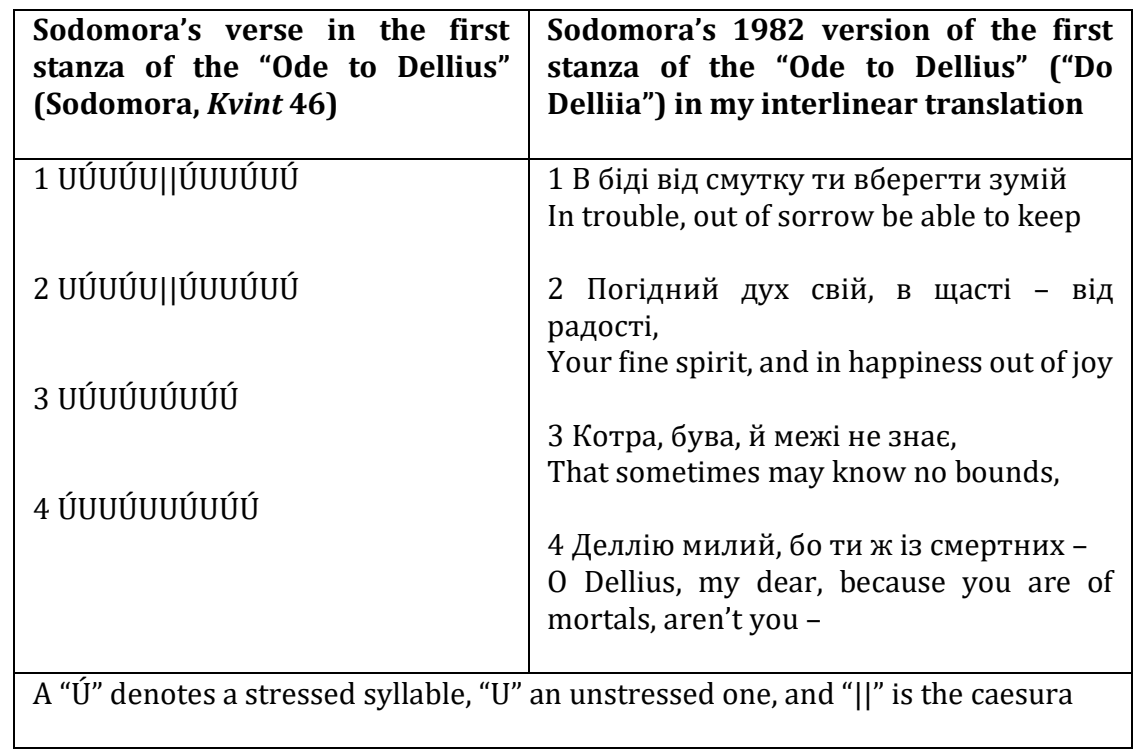

The text produced by Sodomora for the 1982 Ukrainian edition of Horace could be called an "homological translation" or "translationstylization," in the terms of Derzhavyn, while the translation by Zerov falls within the scope of an "analogical translation," which seeks for a recognizable verse form (an analogy) in the domestic poetic culture and relies on easier-to-remember fluency.

In the newer version of the Ode's first stanza, Sodomora keeps pushing forward in his alienating strategy, to such an extent that he is compelled to abandon the Alcaic stanza form-in order to imitate it graphically on the page:

Спокійним пам'ятай справах у скрутних зберігати дух, так само й у сприятливих від надмірної стриманим веселості, вмирущий Деллію... (Studii 58)

Sodomora demonstrates in his experimental translation that without the authentic rhythm and sound pattern, the Horatian word-painting of 
impeccable order and harmony would remain unnoticed by the targetlanguage reader, together with the author's intention to juxtapose and contrast the image-forming words accentuated in the poem. The words seem completely out of order in the Ukrainian text, as if they have been haphazardly scattered on the page, but they do not look random in backtranslation into Latin, where they compose a perfect harmony:

Aequam memento rebus in arduis

servare mentem, non secus in bonis

ab insolenti temperatam

laetitia, moriture Delli...

Table 8 offers a closer examination of Sodomora's version of this stanza (lefthand column). The translation retains the inverted word order of the Latin text so that it reflects an equilibrium which can be compared to the movement of waves. The numbers at the words indicate their grammatically correct place according to natural Ukrainian word order. What would be the stanza's normal word order in Ukrainian is given in the right-hand column and accompanied with my interlinear translation into English.

Table 8. Sodomora's 2006 version of the first stanza of the "Ode to Dellius" (left-hand column), restructured according to the natural Ukrainian word order and with my interlinear translation into English (right-hand column).

\begin{tabular}{|c|c|}
\hline $\begin{array}{l}\text { Sodomora's later version of the } \\
\text { first stanza of the "Ode to Dellius" } \\
\text { (Sodomora, Studii 58) }\end{array}$ & $\begin{array}{l}\text { Sodomora's later version of the first } \\
\text { stanza of the "Ode to Dellius," } \\
\text { restructured according to the natural } \\
\text { Ukrainian word order and with my } \\
\text { interlinear translation into English }\end{array}$ \\
\hline $\begin{array}{l}1 \text { Спокійним }{ }^{4} \text { пам'ятай }{ }^{1} \text { справах }^{6} \\
\text { y скрутних }^{5}\end{array}$ & $\begin{array}{l}\text { Пам'ятай зберігати дух спокійним } \\
\text { Remember to keep a level head }\end{array}$ \\
\hline $\begin{array}{l}2 \text { зберігати }{ }^{2} \text { дух, }{ }^{3} \text { так само й }{ }^{7} \text { y } \\
\text { сприятливих }{ }^{11} \text { - }\end{array}$ & $\begin{array}{l}\text { у скрутних справах, так само й } \\
\text { in difficult matters, similarly, in good times }\end{array}$ \\
\hline 3 від надмірної ${ }^{9}$ стриманим ${ }^{8}$ & $\begin{array}{l}\text { стриманим від надмірної веселості } \\
\text { restrain yourself from immoderate joy, }\end{array}$ \\
\hline 4 веселості, 10 вмирущий Деллію... & $\begin{array}{l}\text { у сприятливих [справах], вмирущий } \\
\text { Деллію... } \\
\text { Dellius, about to die... }\end{array}$ \\
\hline
\end{tabular}


Sodomora's understanding of the ancient Roman poet's world view is embodied in his retranslations from Horace. They bring about an attitude that does not allow one to lose equilibrium and helps to maintain peace of mind-or at least to behave with dignity, as experienced gladiators ("morituri") behave in the arena. As Sodomora remarks in his book, this is the state of mind when a human being is "even in the soul," which is an instance of Horace's aesthetics - a little bit of sorrow in joy, a little bit of joy in sorrow (but not "apathetic," not indifferent). This state of equilibrium gives a possibility to see the world not only with physical sight but also with the sight of one's soul, to "seize the day," catch the moment.

Drawing on the observations of Mikhail Gasparov (1935-2005)—a noted scholar in classical philology and the history of versificationSodomora likens the rhythmic movement in this stanza to the ascending and descending rhythms of waves, with their uprush and backwash: the first half of the first and second lines is the uprush, and the second half of the first and second lines is the backwash; the third line is the uprush, and the fourth one is the backwash (Studii 56-57).

A comparison of the rhythmical and semantic equilibrium of this stanza in Horace and Sodomora, who has also drawn the diagonal and vertical, or reversed diagonal, axes of the first three lines, is given in Table 9.

Table 9. A comparison of rhythmical and semantic equilibrium exemplified by the first stanza of the "Ode to Dellius" in Horace and Sodomora.

\begin{tabular}{|l|l|}
\hline \multicolumn{2}{|l|}{ The first half of the first and second lines (the uprush): } \\
\hline $\begin{array}{l}\text { Aequam memento } \\
\text { servare mentem }\end{array}$ & $\begin{array}{l}\text { Спокійним пам'ятай } \\
\text { зберігати дух }\end{array}$ \\
\hline The second half of the first and second lines (the backwash): \\
\hline $\begin{array}{l}\text { rebus in arduis } \\
\text { non secus in bonis }\end{array}$ & $\begin{array}{l}\text { справаху скрутних } \\
\text { так само й у сприятливих }\end{array}$ \\
\hline $\begin{array}{c}\text { The diagonal axis of the first three lines: } \\
\text { Aequam mentem }\end{array}$ & \begin{tabular}{l} 
Спокійним дух \\
\multicolumn{2}{|c|}{ стриманим }
\end{tabular} \\
\hline
\end{tabular}


Table 9. Cont.

\begin{tabular}{l}
$\begin{array}{l}\text { The vertical / reversed diagonal axis of the first three lines (with the reverse } \\
\text { movement): }\end{array}$ \\
\hline \begin{tabular}{c|c|} 
memento \\
mentem \\
insolenti
\end{tabular} \\
дух \\
надмірной \\
\hline
\end{tabular}

In addition to the problem of rendering the rhythmical patterns and sound structure, there is an even greater difficulty, which is the lexicogrammatical untranslatability of certain Latin word forms. For instance, the form "moriture" (active participle, future tense) in the fourth line of this stanza does not lend itself easily to translation, or even to comprehending. As Sodomora observes, the form "moriture" is exceptionally expressive and combines in itself the attribute (as in the adjective "mortalis") with the action (active voice) and the futurity, which is present in this Latin epithet-not only in the sense that something will happen in its time, and the person characterized by it is meeting his fate, but also in the sense that this person is living in the context of the future, moving toward his death and cannot be free of it at any moment in life; moreover, Dellius is meeting a fate with the inevitable seal of death: "you who are about to die."

Furthermore, Sodomora reinterprets the basic philosophical premise, which is a combination of the "useful" and the "pleasant" in the structure of Horatian lyrical poetry in terms of its translatability. From Sodomora's viewpoint, the "useful" dominates in translation, but the "pleasant," without which there is no poetry, remains untranslated, because it is mostly untranslatable. Therefore, as argued by Sodomora, while the original poem-which per se is a unity of thought and feeling-appeals to the thoughts and feelings of its audience, the translation speaks only to its thoughts. It can render the "useful" in Horace, i.e., his philosophical maxims, but the "pleasant," or the poetic image itself, remains largely untranslated (Sodomora, Studii 60). This premise seems to be the main reason why Sodomora foreignizes his translations, trying to make the Horatian poetic images less familiar and, thus, more appealing to Ukrainian readers.

Besides, his foreignizing strategy points to the importance of intertextual relations of the source work. As a translator, Sodomora emphasizes that a poetic creation consists of both one's own and "somebody else's" material, the use of which is not always conscious by the author but should be traced by an attentive translator; meanwhile, in a paraphrasing translation the intertextual relations of the source work will be mostly eroded and washed away.

Thus, the accuracy of translation, both semantic and structural, has been raised by Sodomora to a new level. He creates a pathway back to the original 
text, so that readers may follow it-not for the sake of an easy walk, but for the sake of learning as well as intellectual pleasure.

\section{CONCLUSION}

While Zerov was working on his "middle-ground" strategy for verse translation that would best serve the interests of the emerging Ukrainianreading mass audience, as follows from his article "Notes on the Case of Verse Translation," his German contemporary Benjamin set out a contrary theoretical framework for translating poetry in his seminal 1923 essay, "The Task of the Translator." Benjamin argues that a work of art is not (and should not be) concerned with the reader's response because "no poem is intended for the reader, no picture for the beholder, no symphony for the listener" (Benjamin 71).

These two outstanding thinkers viewed the task of the translator from the opposite angles: Zerov's perspective was based on the idea of the universality of art, with its moral values that should be comprehensible to the general reader, while Benjamin saw the art of translation as a way to approach transcendental reality. Nevertheless, Zerov and Benjamin were thinking in unison on one fundamental point: classical works should find their afterlife in translation-or, as Benjamin put it, translation should mark "their stage of continued life" (73). If read in the post-Soviet Ukrainian context, Benjamin's philosophy of translation, which declares the equality of languages, may acquire a new relevance to the present-day exigencies of the Ukrainian language-which is unshackling and purifying itself from the negative effects of the Kremlin colonialist project.

In the post-Soviet Ukrainian context, a reformative approach to the tradition of translating the Greek and Roman classics coheres with a neoliteralist perspective, outlined by Benjamin as early as in 1923-which was criticized by Viktor Koptilov in $1973,{ }^{20}$ and praised by Marilyn Rose in

20 The Ukrainian poet-translator and professor of linguistics Viktor Koptilov (19302009) was a literary disciple of Zerov, and he was quick to publish a critical response to Gasparov's essay "Briusov i bukvalizm" ("Briusov and Literalism"), published in Masterstvo perevoda (The Craft of Translation) in 1971, in which Gasparov positively thematizes the three stages of literalism in Briusov's retranslation of The Aeneid by Virgil. In his article "I vshyr', i vglub'..." ("Both Sideways and in Depth..."), which appeared in the next volume of The Craft of Translation in 1973, Koptilov condemned any reasons put forward by Gasparov in favour of Briusov's neo-literalist approach to translating works from antiquity. 
1993,21 and was also substantiated by Douglas Robinson, Tejaswini Niranjana, and others.

The landmark nature of Benjamin's resurgence in the late twentiethcentury turn in translation studies points to the importance of his concepts for anti-imperialist and post-colonial theories in the field of translation. Benjamin's literalism appears in the spotlight of descriptive (nonprescriptive) and post-colonial translation studies. In opposition to traditional content- (meaning-) centred approaches, or retelling the classics in the language of contemporaneity, with its inexorable "theological" reduction of the source text to meaningful content that serves as a semantic equivalent of the "spirit" or "soul," Robinson elaborates a new and meaningdecentring typology of translations (The Translator's Turn). His approach pivots on the idea of the dialogical nature of translation and the ethics of form. It suggests understanding the process of translation as the translator's polylogue with the author and reader(s). Robinson's turn to an intuitive, personal, and ethical model that confides in the "feeling" of language develops a neo-literalist notion of translation as a non-finalized, open-ended (co)creation.

In the light of Russia's cultural imperialism, the concept of neoliteralism, based on the ideas of Benjamin, as an arcade and approximation to the purposiveness of the source language and a non-discriminatory movement between languages in "an interliminal space of meaning, allusion and sound" becomes particularly relevant at this time of Ukrainian cultural decolonization (Rose, Translation 73). A traditional, assimilative approach to understanding translation as a representation of the original work has been instrumental in the formation of totalitarian myths. Meanwhile, in representing the original a colonized translator really saturates his/her representation with a kind of "otherness" to and difference from the colonizing culture. What the colonized translator's representation in fact offers is a set of metaphysical visions of, and insights into, the state of his/her national culture. No wonder, then, that when studying the tropes and tricks of colonial discourse, Niranjana notices an important revisionist tendency in the post-colonial society, which she calls a "desire to retranslate," and she associates it with a "desire to re-write history" (172). Niranjana admits that reading existing translations is the same as reading historiography from a

\footnotetext{
${ }^{21}$ A distinguished scholar in the field of translation studies, Rose observed in her report at the 34th Annual Conference of the American Translators' Association in 1993 that a new, sophisticated literalism (she suggested the same term-neoliteralism - as Koptilov had done in his article "Both Sideways and in Depth...") had really come to the fore, both in the theory and practice of Western translation. Rose further developed the concept of neo-literalism, based on the ideas of Benjamin ("Foreignizing or Domesticating").
} 
post-colonial perspective. A reader attentive to the tricks of colonial discourse would discover herein an entire history of resistance, as well as an underlying tension and difference from the colonizing culture.

Post-colonial retranslations of the classics by Sodomora and his innovative ideas have made him one of the key thinkers in the field of translation studies in post-Soviet Ukraine. His works are indicative of a new stage in the present-day development of translation studies: from the singsong nature of regular metres and creative paraphrasing as the basic device for rendering the source text's semantic content to an accurate and detailed reproduction of the sources (inter)text in its entirety and complexity.

Sodomora argues for a reconsideration of the Ukrainian canon of the Roman classics, founded in the early 1920 s by Zerov and like-minded Neoclassical poets and crowned in the early 1970s by Koptilov with the idea of a "golden mean," understood as a balance between creativity and fidelity in translation (Koptilov 261). Moreover, in his retranslations of Horace, which are not only classically metrical and unrhymed but also appear much closer to the source text's (inverted) word order than earlier versions, Sodomora launched a revision of Zerov's tradition of paraphrasing the classics. Zerov cherished self-discipline, classical rigour of form, and clarity of thought in translation, but he oriented his works at the average reader. On the other hand, in his retranslations of Horace Sodomora does not sacrifice accuracy for fluency, although his texts remain comprehensible. From that perspective, his retranslating strategy highlights exceptionality rather than temperance in classical poetry.

At the same time, Sodomora's neo-literalist strategy illustrates Benjamin's thought that "any translation of a work originating in a specific stage of linguistic history represents, in regard to a specific aspect of its content, translation into all other languages" (76-77). This assertion is further corroborated in Benjamin when he points at the translator's invisibility and objectivity concerning the source text: a "real translation" should be transparent, it should not "cover the original" (79).

The retranslating experience of Sodomora, therefore, as well as his reasoning for it, fits into Benjamin's guidance to "lovingly and in detail incorporate the original's mode of signification" and his idea of "making both the original and the translation recognizable as fragments of a greater language, just as fragments are part of a vessel," instead of simply resembling the meaning of the original (79). A neo-literalist strategy that corresponds to this instruction would "turn the symbolizing into the symbolized," which in Benjamin's view is "the tremendous and only capacity of translation" (80).

All in all, Sodomora's strategy is not governed by the idea of making the translation sound better in Ukrainian or getting it to deliver the content more clearly. To the contrary, he allows his native tongue to be affected by 
the Latin language, which penetrates his (re)translations to the point where the sound, the tone, and the image converge. His translation practice has thus evolved into a quiet dialogue with the original, written without the readability of a broad audience in mind. It is an echo of the Horatian text, which was not intended for a broad audience, either.

It may be argued that at the turn of a new millennium, Zerov's focus on the importance of conveying the form and style of the original as accurately as possible prompted Sodomora to evolve his neo-literalist retranslating strategy. Specifically, his earlier translations from Horace underwent a maturing process to such an extent as to chime with Benjamin's frame of thought: "Languages are not strangers to one another, but are, a priori and apart from all historical relationships, interrelated in what they want to express" (74). This is a decidedly anti-imperialistic way of thinking, and a liberating one for the still-subaltern Ukrainian tongue, which after 70 years of Soviet rule (and, until recently, years of virtual inaction by the independent Ukrainian government) needs renewal and purification from the moulds of its Russified version. A neo-literalist rethinking of Ukrainian translation helps to replace the Russified and deadened language patterns of the Soviet period and to rejuvenate the language, which has become stiffened and decayed to a large extent under the influence of Soviet-era Russian as an imperialistic language-mediator.

After colonial stagnation, the Ukrainian language needs translations that not only convey the meaning(s) of the classical texts but produce poetic works of distinction. Having decentralized meaning, these kinds of translations will put the Ukrainian language to the test, giving it a real jolt and extending its boundaries. In that regard, Sodomora's strategy, which is to effect a close reading of the original by means of translation, has a contiguous relation to Benjamin's argument for literariness: "If the kinship of languages manifests itself in translations, this is not accomplished through a vague alikeness between adaptation and original" (75). Benjamin's reasoning has received a new application in the post-Soviet context of Ukrainian linguistic reality. And what Sodomora clearly demonstrates in his (re)translations is, to use Benjamin's idiom, "the harmony of the languages," their complementarity in the mode of intention, and equality in creative potential (82). What's more, the long journey into the world of classical authors taken by Sodomora has been perceived as a viable response to Zerov's call "Ad fontes!" and pays tribute to Zerov as a great teacher with a lasting legacy. 
Works Cited

Annenskii, Innokentii. Razbor stikhotvornogo perevoda "Liricheskikh stikhotvorenii Goratsiia” P. F. Porfirova. Tipografiia Imperatorskoi Akademii Nauk, 1904.

The Art of Poetry An Epistle to the Pisos: Q. Horatii Flacci Epistola ad Pisones, De Arte Poetica. archive.org/stream/theartofpoetryan09175gut/7artp10.txt. Accessed 29 July 2019.

Bilets'kyi, O. I., editor. Commentary. Kvint Horatsii Flakk: Poezii. Antychna literatura: Khrestomatiia, translated by Mykola Zerov, edited by Bilets'kyi, 2nd ed., Radians'ka shkola, 1968, pp. 466-67. http://aelib.org.ua/texts/horatius poetry by zerov ua.htm. Accessed 20 Jan. 2019

Benjamin, Walter. "The Task of the Translator." Theories of Translation: An Anthology of Essays from Dryden to Derrida, translated by Harry Zohn, edited by Rainer Schulte and John Biguenet, The U of Chicago P, 1992, pp. 71-82.

Chukovskii, Kornei and Andrei Fedorov. Iskusstvo perevoda. ACADEMIA, 1930.

Derzhavyn, Volodymyr. "Problema virshovanoho perekladu." Pluzhanyn, nos. 9-10 (13-14), 1927, pp. 44-51.

Fet, Afanasii, translator. $O$ poeticheskom iskusstve. By Horace, 1883. http://lib.ru/POEEAST/GORACIJ/hor3 1.txt. Accessed 18 Jan. 2019.

Finkel', Oleksandr. Teoriia i praktyka perekladu. DVU, 1929.

Gasparov, Mikhail. "Briusov i bukvalizm. (Po neizdannym materialam k perevodu Eneidy)." Masterstvo perevoda, vol. 8, 1971, pp. 88-128.

Horace. Ode 1.11. Odes and Epodes. Edited by Paul Shorey and Gordon J. Laing, Benj. H. Sanborn \& Co., 1919.

http://www.perseus.tufts.edu/hopper/text?doc=Perseus\%3Atext\%3A1999.02 $.0024 \% 3$ Abook\%3D1\%3Apoem\%3D11. Accessed 29 June 2018.

---. Ode 2.3. Odes and Epodes. Edited by Paul Shorey and Gordon J. Laing, Benj. H. Sanborn

\&

Co.,

1919.

http://www.perseus.tufts.edu/hopper/text?doc=Perseus\%3Atext\%3A1999.02 $.0024 \% 3$ Abook\%3D2\%3Apoem\%3D3. Accessed 27 June 2018.

---. Ode 3.30. Odes and Epodes. Edited by Paul Shorey and Gordon J. Laing, Benj. H.

Sanborn

$\&$

Co.,

1919.

http://www.perseus.tufts.edu/hopper/text?doc=Perseus\%3Atext\%3A1999.02 $.0024 \% 3$ Abook\%3D3\%3Apoem\%3D30. Accessed 30 June 2018.

Kline, A. S., translator. The Odes: Book II. By Horace, Poetry in Translation, 2003. https://www.poetryintranslation.com/PITBR/Latin/HoraceOdesBkII.php.

Accessed 27 Dec. 2018.

---. The Odes: Book III. By Horace, Poetry in Translation, 2003. https://www.poetryintranslation.com/PITBR/Latin/HoraceOdesBkIII.php.

Accessed 29 Dec. 2018.

Kondrat'ev, Sergei P., editor. Rimskaia literatura v izbrannykh perevodakh. Sovetskii pisatel', 1939.

Koptilov, Viktor. “I vshyr', i vglub'....” Masterstvo perevoda, vol. 9, 1973, pp. 257-61.

Lavrinenko, Iurii. Rozstriliane vidrodzhennia. Antolohiia 1917-1933: poeziia, proza, drama, esei. Instytut Literacki, 1959. 
Maifet, Hryhorii. Review of Teoriia i praktyka perekladu, by 0. Finkel. Chervonyi shliakh, no. 12, 1929, pp. 149-253. Reprint in O. A. Kalnychenko and Iu. Iu. Poliakova. Ukrains'ka perekladoznavcha dumka 1920-kh - pochatku 1930-kh rokiv: Khrestomatiia vybranykh prats' z perekladoznavstva, edited by Leonid Chernovatyi and Viacheslav Karaban, Nova Knyha, 2011, pp. 376-91.

---. "Z uvah do teorii perekladu." Krytyka, vol. 3, 1928, pp. 84-93.

Niranjana, Tejaswini. Siting Translation: History, Post-Structuralism, and the Colonial Context. U of California P, 1992.

Orest, Mykhailo. "Zeroviana." Catalepton: Ukrainian Poems, by Mykola Zerov, edited and with afterword by Mykhailo Orest, 1951, pp. 61-64.

Pauly, Matthew D. Breaking the Tongue: Language, Education, and Power in Soviet Ukraine. U of Toronto P, 2014.

Pavlychko, Dmytro. "Bezsmertnyi maister." Tvory v dvokh tomakh. Tom 1: Poezii. Pereklady, by Mykola Zerov, edited by H. P. Kochur and D. V. Pavlychko, Dnipro, 1990, pp. 14-20.

Robinson, Douglas. The Translator's Turn. Johns Hopkins UP, 1991.

---. Translation and Empire: Postcolonial Theories Explained. St. Jerome, 1997.

---. Translation and Taboo. Northern Illinois UP, 1996.

Rose, Marilyn Gaddis. "Foreignizing or Domesticating: Debating Norms Goes with the Territory." Keystones of Communication: Proceedings of the 34th Annual Conference of the American Translators Association, edited by in Edith F. Losa, Learned Information, 1993, pp. 265-71.

---. Translation and Literary Criticism: Translation as Analysis. St. Jerome Publishing, 1997.

Savchenko, Iurii. “Pochyn.” Pluzhanyn, nos. 9-10 (13-14), 1927, pp. 63-71.

Shevchenko-Savchynska, Lyudmyla, and Kostyantyn Balashov. Ancient Literature Breaking Down Stereotypes. Translated by Elvira Shvets, CreateSpace Independent Publishing Platform, 2014.

Shkandrij, Myroslav. Modernists, Marxists and the Nation: The Ukrainian Literary Discussion of the 1920s. Canadian Institute of Ukrainian Studies P, 1992.

Sodomora, Andrii, translator. Kvint Horatsii Flakk. Tvory. Dnipro, 1982

---. Studii odnoho virsha. Litopys, 2006.

Venuti, Lawrence, ed. Rethinking Translation: Discourse, Subjectivity, Ideology. Routledge, 1992.

---. The Translator's Invisibility: A History of Translation. Routledge, 1995.

Zahais'ka, H. M. "Ody Horatsiia v ukrains'kykh perekladakh.” Naukovyi visnyk Chernivets'koho universytetu. Hermans'ka filolohiia, vols. 692-93, 2014, pp. 3-39.

Zerov, Mykola. Do dzherel: literaturno-krytychni statti. Slovo, 1926.

---, translator. Kvint Horatsii Flakk: Poezii. Antychna literatura: Khrestomatiia, edited by O. I. Bilets'kyi, 2nd ed., Radians'ka shkola, 1968, pp. 458-83.

---. Tvory v dvokh tomakh. Tom 1: Poezii. Pereklady. Edited by H. P. Kochur and D. V. Pavlychko, Dnipro, 1990.

---. "U spravi virshovanoho perekladu. Notatky." Zhyttia i revoliutsiia, vol. IX, Sept. 1928, pp. 133-46. 